Key Words: Uranium, Technetium, Spent Fuel, Transmutation

Retention: Permanent

\title{
DEMONSTRATION OF THE UREX SOLVENT EXTRACTION PROCESS WITH DRESDEN REACTOR FUEL SOLUTION
}

M. C. Thompson, M. A. Norato, G. F. Kessinger,

R. A. Pierce, T. S. Rudisill, and J. D. Johnson

September 30, 2002 
This document was prepared in conjunction with work accomplished under Contract No. DE-AC09-96SR18500 with the U. S. Department of Energy.

\section{DISCLAIMER}

This report was prepared as an account of work sponsored by an agency of the United States Government. Neither the United States Government nor any agency thereof, nor any of their employees, makes any warranty, express or implied, or assumes any legal liability or responsibility for the accuracy, completeness, or usefulness of any information, apparatus, product or process disclosed, or represents that its use would not infringe privately owned rights. Reference herein to any specific commercial product, process or service by trade name, trademark, manufacturer, or otherwise does not necessarily constitute or imply its endorsement, recommendation, or favoring by the United States Government or any agency thereof. The views and opinions of authors expressed herein do not necessarily state or reflect those of the United States Government or any agency thereof.

This report has been reproduced directly from the best available copy.

Available for sale to the public, in paper, from: U.S. Department of Commerce, National Technical Information Service, 5285 Port Royal Road, Springfield, VA 22161, phone: (800) 553-6847, fax: (703) 605-6900

email: orders@ntis.fedworld.gov

online ordering: http://www.ntis.gov/help/index.asp

Available electronically at http://www.osti.gov/bridge

Available for a processing fee to U.S. Department of Energy and its contractors, in paper, from: U.S. Department of Energy, Office of Scientific and Technical Information, P.O. Box 62, Oak Ridge, TN 37831-0062,

phone: (865)576-8401,

fax: (865)576-5728

email: $\underline{\text { reports@ adonis.osti.gov }}$ 
WSRC-TR-2002-00444

Revision 0

REVIEWS AND APPROVALS

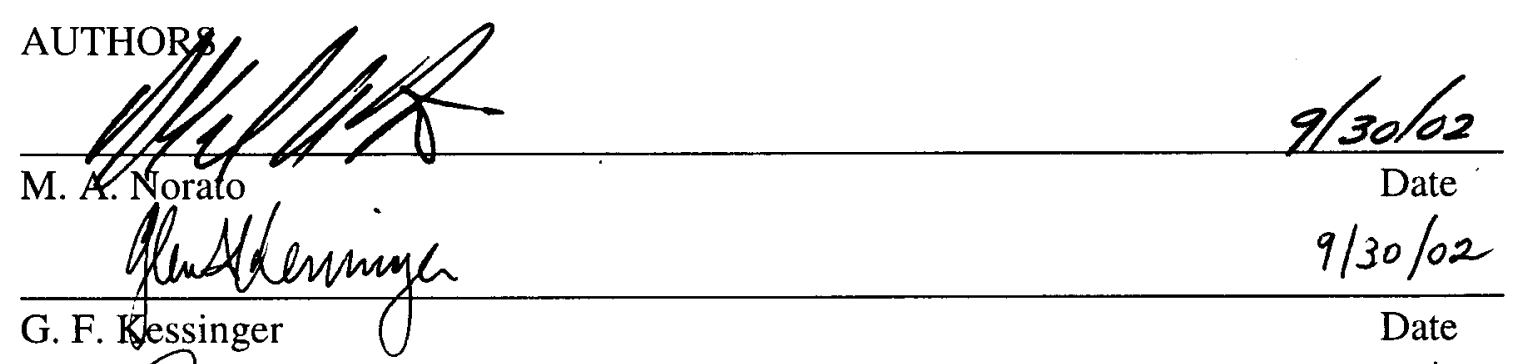
Robot Bier $\frac{9 / 30 / 02}{\text { Date }}$

R. A. Pierce $\frac{9 / 30 / 02}{\text { Date }}$
$\frac{4 / 30 / 02}{\text { Date }}$

T. S. Rudisill

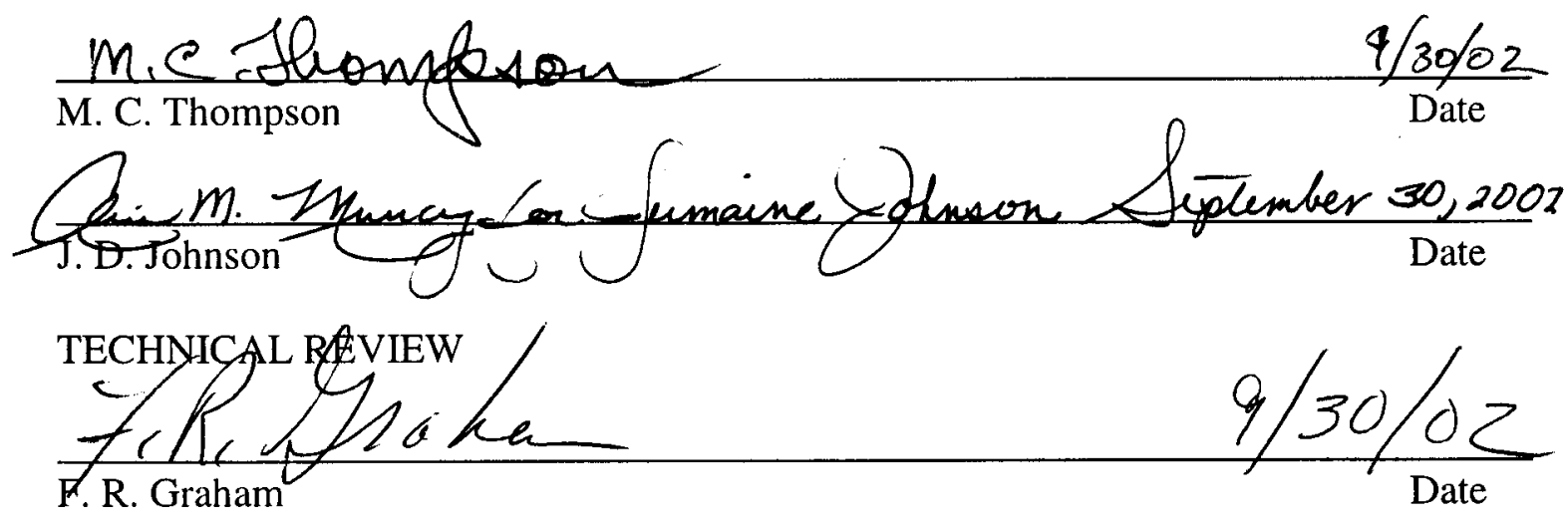

MANAGEMENT APPROVAL

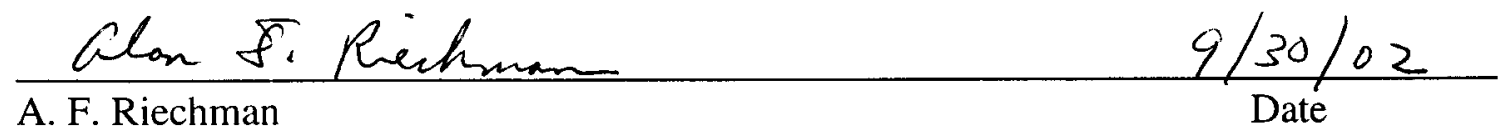

iii 


\section{Table of Contents}

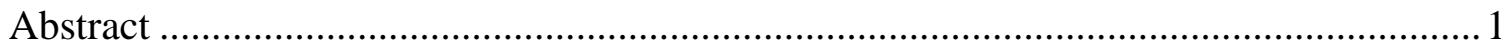

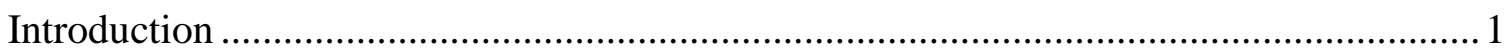

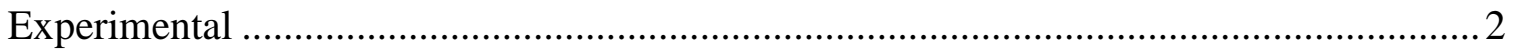

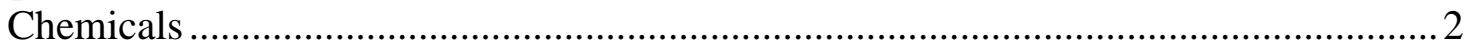

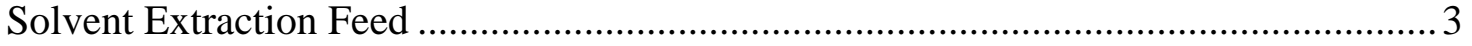

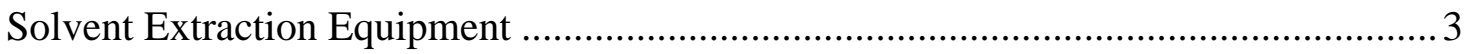

Solvent Extraction Tests............................................................................. 7

Hydraulic Testing ......................................................................................... 7

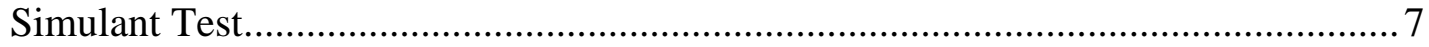

Dresden Fuel Solution Tests ........................................................................... 7

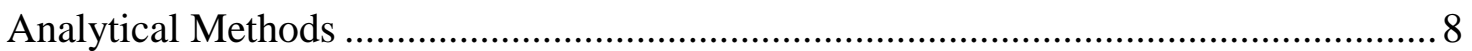

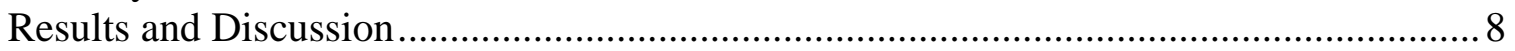

UREX Solvent Extraction Testing ..................................................................... 8

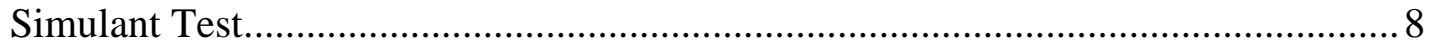

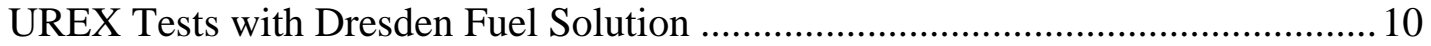

UREX Hot Demonstration Test 1 ............................................................... 10

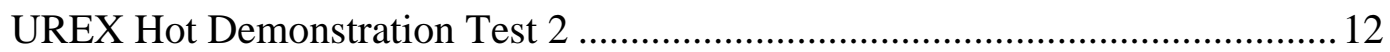

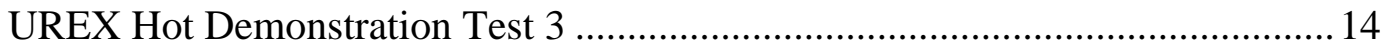

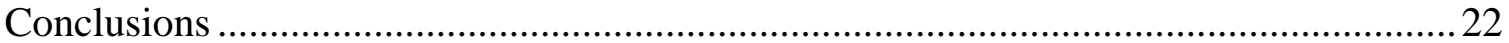

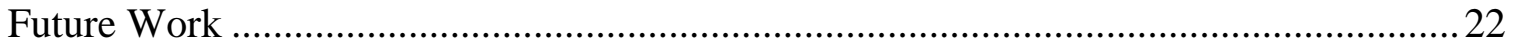

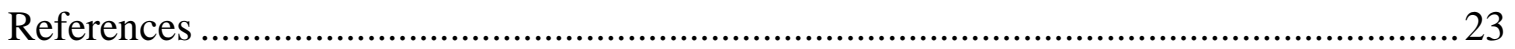


WSRC-TR-2002-00444

Revision 0

\section{List of Figures}

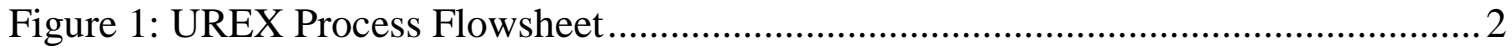

Figure 2: UREX Process Flow Diagram in Shielded Cell .............................................. 4

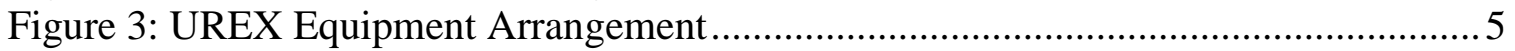

Figure 4: Feed Tank for UREX Solvent Extraction Tests ....................................... 6

Figure 5: Simulant Test Flow Ratios ................................................................... 9

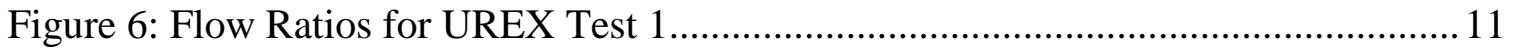

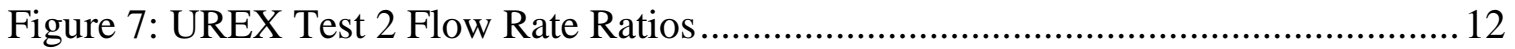

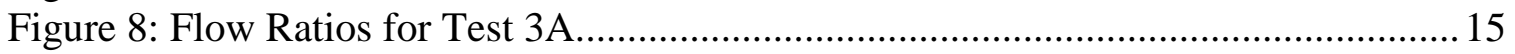

Figure 9: Calculated Decrease in AHA Concentration during Test 3 ........................... 21

\section{List of Tables}

Table I: UREX Feed Solution Composition ............................................................... 3

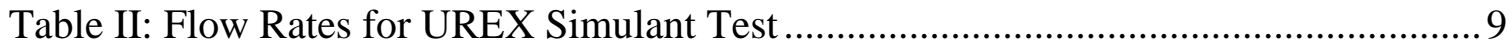

Table III: Mass Balance for UREX Simulant Test....................................................... 10

Table IV: End Stream Analyses from UREX Hot Demonstration Test 1....................... 11

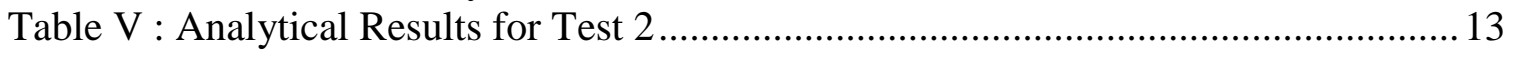

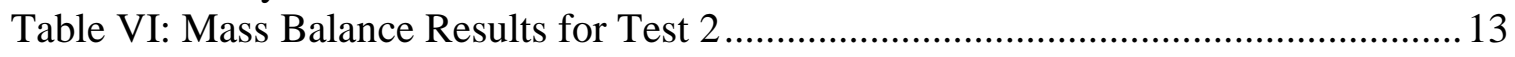

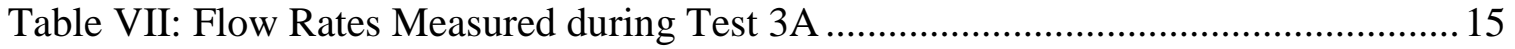

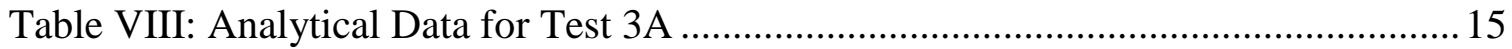

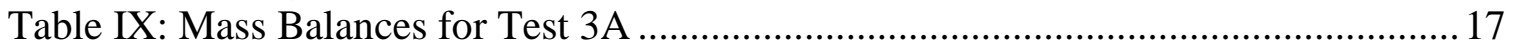

Table X: Comparison of Baseline Flow Rates and Flow Rates for Test 3B ................... 17

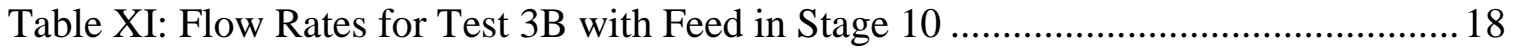

Table XII: Flow Rates for Test 3B with Feed in Stage 8 ......................................... 18

Table XIII: Analytical Data for Test 3B with Feed in Stage 10................................... 19

Table XIV: Mass Balances for Test 3B with Feed in Stage 10..................................... 19

Table XV: Analytical Data for Test 3B with Feed in Stage 8 .................................... 19

Table XVI: Mass Balances for Test 3B with Feed in Stage 8 .......................................20

Table XVII: Summary of Test Results and Low Level Waste Classes...........................22 
WSRC-TR-2002-00444

Revision 0

\section{Abstract}

A solvent extraction process to recover uranium and technetium from solutions of irradiated commercial reactor fuel while sending the plutonium to waste with the fission products and higher actinides was tested with actual fuel solution. Demonstration of the uranium extraction (UREX) process at baseline conditions showed that the process meets all goals for recovery and decontamination. The goals for the UREX process are to produce a $\mathrm{U}$ product that is Class $\mathrm{C}$ low level waste or lower, recover $>99.9 \%$ of the $\mathrm{U}$ and $>95 \%$ of the $\mathrm{Tc}$, reject $>99.9 \%$ of the $\mathrm{Pu}$ to the raffinate, and maintain the $\mathrm{U}$ concentration in the Tc product $<0.01 \%$ of the Tc. All three tests showed Cs being lower than the Class A limit of $1 \mathrm{Ci}$ per cubic meter. Strontium was low Class B for the first two tests and very close Class A in the third test (the Sr was below the detectability limit of the method in the third test). In fact, the third test resulted in a TRU isotope concentration of only $16 \mathrm{nCi}$ per gram of $\mathrm{U}$. The $\mathrm{U}$ losses to the Tc and raffinate streams totaled $0.011 \%$ of the $U$ fed to the process in the first test. $U$ loss to the raffinate was $0.016 \%$ in the second test.

Tc losses to the U stream were $1.2 \%$ in the first test and $0.1 \%$ in the second test while losses to the raffinate were so low they could not be measured in the first test. Data is not available yet for the other two tests. These results indicate that $>95 \%$ of Tc can be recovered from the feed.

Loss of $\mathrm{Pu}$ and other actinides to the Tc and $\mathrm{U}$ product streams was $<0.02 \%$ in all three tests of the baseline flowsheet with $>99.98 \%$ going to the raffinate.

\section{Introduction}

Transmutation of waste is being developed to address disposal of commercial nuclear fuel and improve the performance of the geologic repository ${ }^{1}$. The transmutation program will separate commercial fuel into (1) a transuranium (TRU) product stream that will be further processed, converted to fuel, and transmuted by fissioning to generate electrical power, (2) separate technetium-99 $\left({ }^{99} \mathrm{Tc}\right)$ and iodine-129 $\left({ }^{129} \mathrm{I}\right)$ streams, which will be converted into targets for transmutation to short-lived nuclides, and (3) a uranium product (UP) stream that meets the criteria for Class C low-level waste.

The Plutonium and Uranium Extraction (PUREX) process is a mature solvent extraction process for irradiated nuclear fuel that was designed to recover plutonium $(\mathrm{Pu})$ and $\mathrm{U}$. A variation of the PUREX process was conceived to provide the ability to treat the large quantities of irradiated spent fuel and to provide the selectivity required for the process. The PUREX process was changed so that only $U$ and Tc are extracted and the TRU isotopes go to the aqueous raffinate along with the fission products. This Uranium Extraction process is called UREX (see Figure 1). The U solution from UREX is converted to uranium trioxide and the raffinate is evaporated and calcined to produce an oxide product that can be further treated by pyrochemical processing to separate the TRU isotopes from fission products. The raffinate could also be fed to other aqueous processes that recover $\mathrm{Np}$ and $\mathrm{Pu}$ together as well as cesium (Cs) and strontium ( $\mathrm{Sr}$ ). The Tc will be recovered from solution and converted into a target for irradiation. The process will use centrifugal contactors in order to minimize chemical and radiation damage to the solvent. 
The ${ }^{129}$ I will be volatilized during dissolution and recovered from the offgas.

The goals for the UREX process are to recover $>99.9 \%$ of the U and $>95 \%$ of the Tc in different product streams while rejecting $>99.9 \%$ of the TRU isotopes to the raffinate. The $\mathrm{U}$ product is to meet the requirements for Class $\mathrm{C}$ waste or lower for both fission products and TRU. Thus, the $\mathrm{UO}_{3}$ product must contain $<100 \mathrm{nCi}$ of TRU per gram. The process must minimize the waste volume produced during processing. In order to minimize waste, all chemicals used in the process must be converted to gases during subsequent processing. In order to meet this requirement the process was designed to use acetohydroxamic acid (AHA) which complexes $\mathrm{Pu}$ (IV) and $\mathrm{Np}$ (IV) preventing them from extracting and reduces $\mathrm{Np}(\mathrm{VI})$ to inextractable $\mathrm{Np}(\mathrm{V})^{2-7}$. The flowsheet has been successfully tested with simulated solutions in batch and centrifugal contactor tests at Argonne National Laboratory (ANL). ${ }^{8}$ The tests reported here demonstrate the UREX process using solution from dissolved irradiated commercial reactor fuel from the Dresden Reactor. ${ }^{9}$

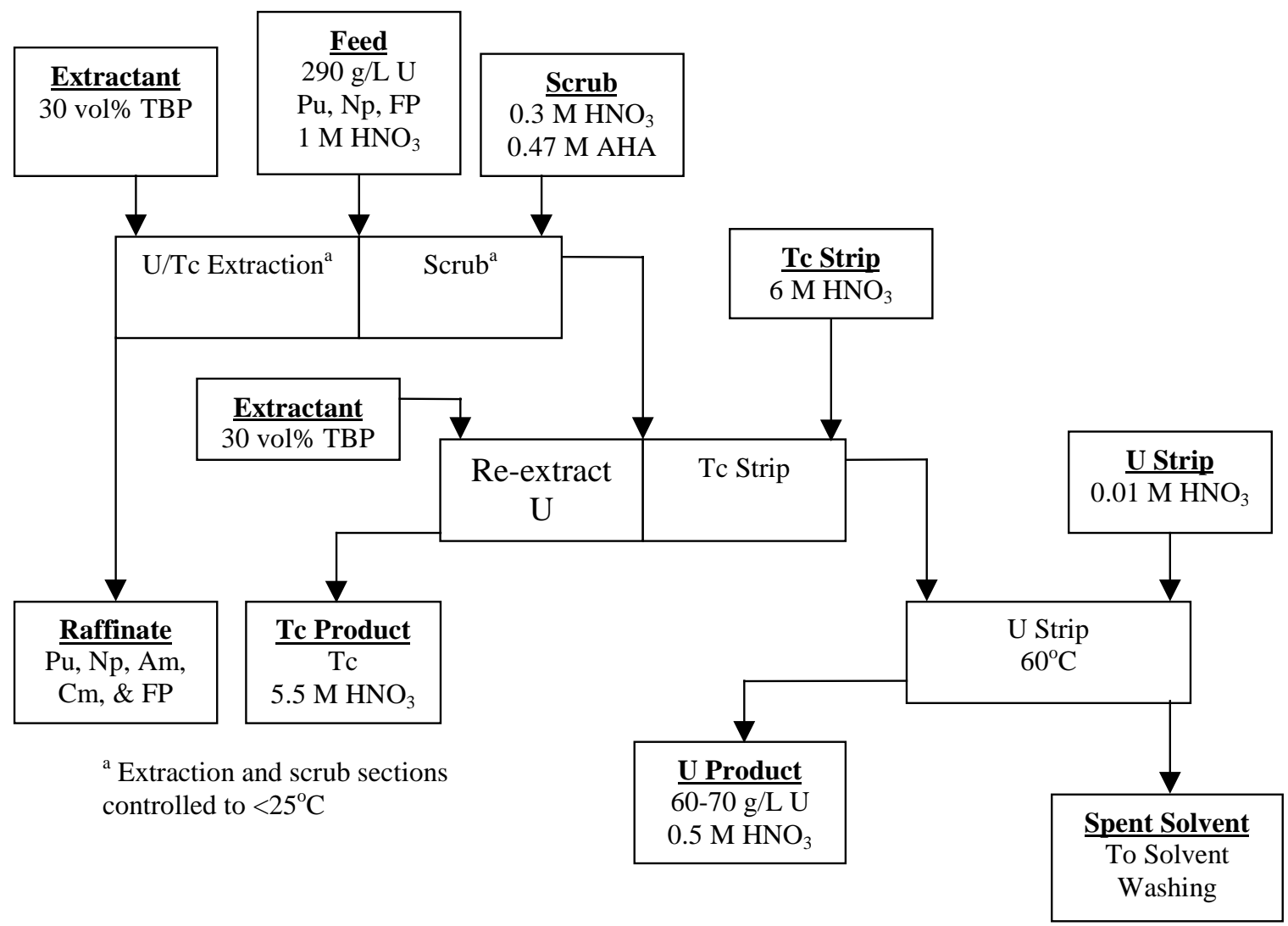

Figure 1: UREX Process Flowsheet

\section{Experimental}

\section{Chemicals}

Acetohydroxamic acid (AHA), $98 \%$ pure, was obtained from Aldrich Chemical Co. and was dissolved in distilled water to produce a $0.94 \mathrm{M}$ solution. Reagent grade $\mathrm{HNO}_{3}$, 69- 
WSRC-TR-2002-00444

Revision 0

$71 \mathrm{wt} \%$ from Fisher Scientific Co. was diluted with distilled water to make acid solutions of $0.3,0.6,1.0$ and $6 \mathrm{M}$ for solvent extraction tests. The scrub solution for UREX tests was prepared by mixing equal volumes of $0.6 \mathrm{M} \mathrm{HNO}_{3}$ and $0.94 \mathrm{M} \mathrm{AHA}$ together in the scrub feed tank immediately before starting to fill the contactors for the test. This was done to minimize acid hydrolysis of AHA.,7

The solvent, 30 vol\% tributylphosphate (TBP), was prepared from $100 \%$ TBP and nparaffin obtained from Savannah River Site plant stocks. The n-paraffin is a mixture of C12 to C16 n-paraffins with low aromatic content. After preparation, the $30 \mathrm{vol} \% \mathrm{TBP}$ solution was washed first with $5 \mathrm{wt} \% \mathrm{Na}_{2} \mathrm{CO}_{3}$ (reagent grade chemical from Fisher Scientific Co.) to remove dibutylphosphoric acid and other impurities and then $0.01 \mathrm{M}$ $\mathrm{HNO}_{3}$ to re-acidify the solvent. The solvent was then stored in glass until needed for tests.

\section{Solvent Extraction Feed}

The solvent extraction feed solution was prepared by diluting solution obtained from the dissolution of Dresden Reactor fuel with $0.1 \mathrm{M}$ and $3 \mathrm{M} \mathrm{HNO}_{3} .{ }^{9}$ Table I shows the composition of the main components in the feed solution.

Table I: UREX Feed Solution Composition

\begin{tabular}{|l|l|}
\hline Component & Analytical Results \\
\hline Free Acid, M & 0.84 \\
\hline U, g/L & 302 \\
\hline Pu, g/L & 1.96 \\
\hline $\mathrm{Np}, \mathrm{g} / \mathrm{L}$ & $6.8 \mathrm{E}-05$ \\
\hline $\mathrm{Am}, \mathrm{g} / \mathrm{L}$ & $1.18 \mathrm{E}+09$ \\
\hline $\mathrm{Cm}, \mathrm{g} / \mathrm{L}$ & \\
\hline${ }^{99} \mathrm{Tc}, \mathrm{g} / \mathrm{L}$ & $1.68 \mathrm{E}-04$ \\
\hline${ }^{137} \mathrm{Cs}, \mathrm{d} / \mathrm{m} / \mathrm{mL}$ & $2.16 \mathrm{E}+10$ \\
\hline${ }^{90} \mathrm{Sr}, \mathrm{d} / \mathrm{m} / \mathrm{mL}$ & $2.26 \mathrm{E}+10$ \\
\hline${ }^{154} \mathrm{Eu}, \mathrm{d} / \mathrm{m} / \mathrm{mL}$ & $1.99 \mathrm{E}+08$ \\
\hline${ }^{155} \mathrm{Eu}, \mathrm{d} / \mathrm{m} / \mathrm{mL}$ & $3.99 \mathrm{E}+07$ \\
\hline
\end{tabular}

There are uncertainties in the $\mathrm{Pu}$ concentration because dilution of the sample to remove from the shielded cell was so high that the uncertainty in the alpha counting was high. Additional analyses are incomplete at this time.

\section{Solvent Extraction Equipment}

The process equipment for extraction and Tc stripping consisted of a 32-stage, 2-cm annular centrifugal contactor apparatus installed in shielded cells at SRTC and used previously in demonstrations of a solvent extraction process for removal of cesium from SRS waste solutions. ${ }^{10}$ As a result of previous use, the contactor was flushed extensively and reconfigured for the UREX process. ANL personnel designed and fabricated the contactor stages. The number of stages in the shielded facility was only sufficient to 
WSRC-TR-2002-00444

Revision 0

demonstrate U/Tc extraction and scrubbing and technetium stripping portions of the process. Four centrifugal contactor stages set up in a radiochemical hood will be used to strip the uranium from the loaded solvent. Figure 2 shows the process flow diagram for the arrangement in the shielded cells.

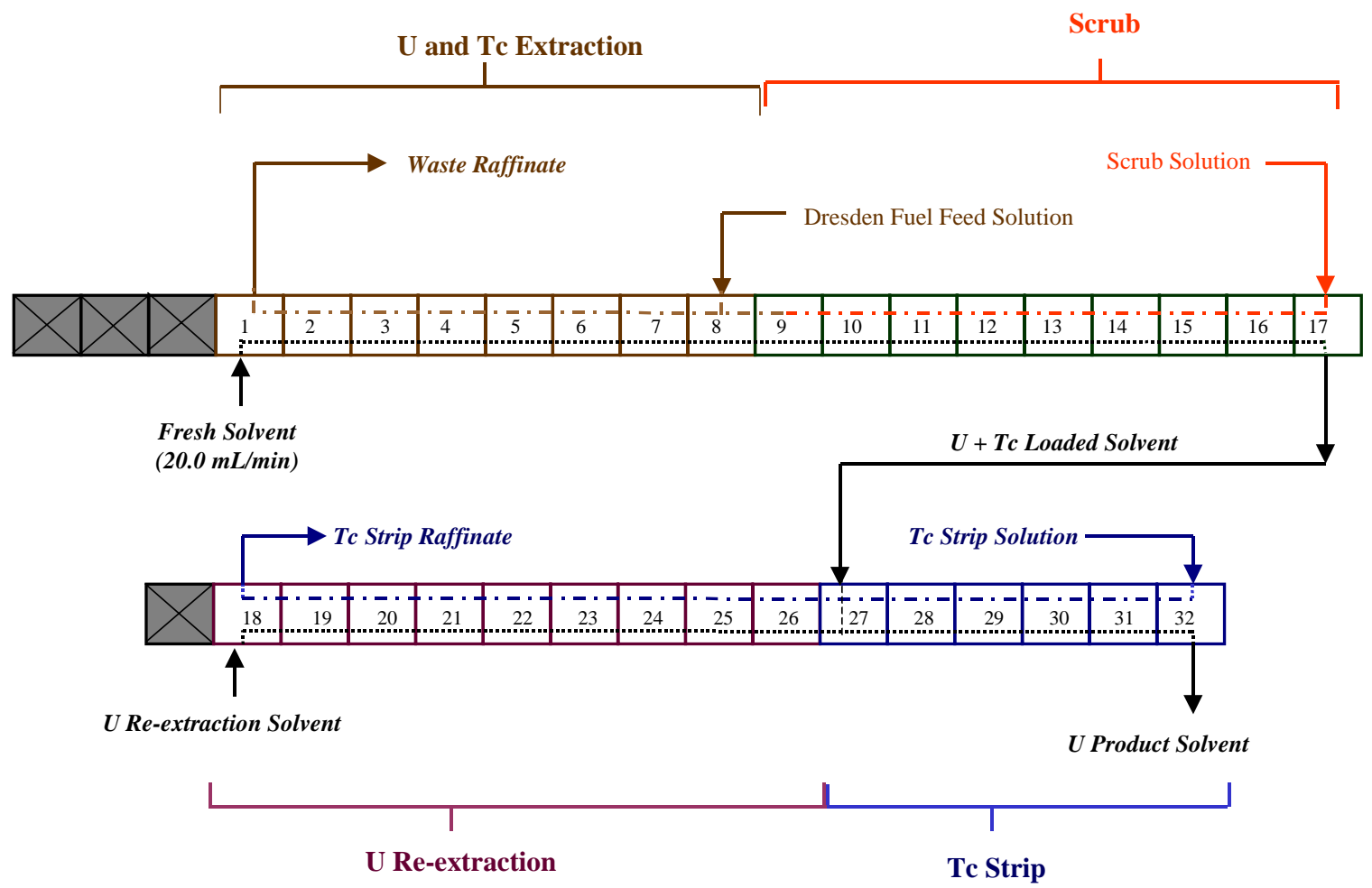

Figure 2: UREX Process Flow Diagram in Shielded Cell

Circulating cooling water maintained the temperature in stages $1-15$ below $25^{\circ} \mathrm{C}$ to ensure Tc extraction. During the first two tests, a NesLab RTE-111 was used for temperature control. However, the NesLab chiller had problems maintaining temperature during the latter part of the second test. A new chilling system was provided by using a large chiller outside the cell to provide $6-8^{\circ} \mathrm{C}$ cooling water to a water bath in a dewar inside the cell. The dewar contained a heater to adjust the temperature of the water to $12-$ $14^{\circ} \mathrm{C}$. The cooled water was pumped through channels located on stages 1-15. Type K thermocouples were attached to the body of the contactor stages and connected to a computer for recording temperature data. The temperatures are measured on the surface of the contactor stages so the actual solution temperatures may be lower by $1-3{ }^{\circ} \mathrm{C}$.

Positive displacement piston pumps manufactured by Fluid Metering, Inc. (FMI) were used for both organic streams and the scrub stream to the contactors. Masterflex peristaltic pumps from Cole Parmer Instrument Co. were used for the fuel feed and Tc strip streams. The initial set of Masterflex pumps contained microprocessors to control the flow rate. However, the Tc strip pump failed after use in the first two tests and was replaced with a pump with analog control. All pumps were calibrated prior to introduction into the shielded cell. All pumps except the scrub feed pump were operated 
under manual control throughout the test. The scrub pump rate was controlled from the computer using the flow instrumentation from previous testing, but the flow rate was offset due to the difference in scrub stream properties. Figure 3 shows the layout of equipment in the shielded cell.

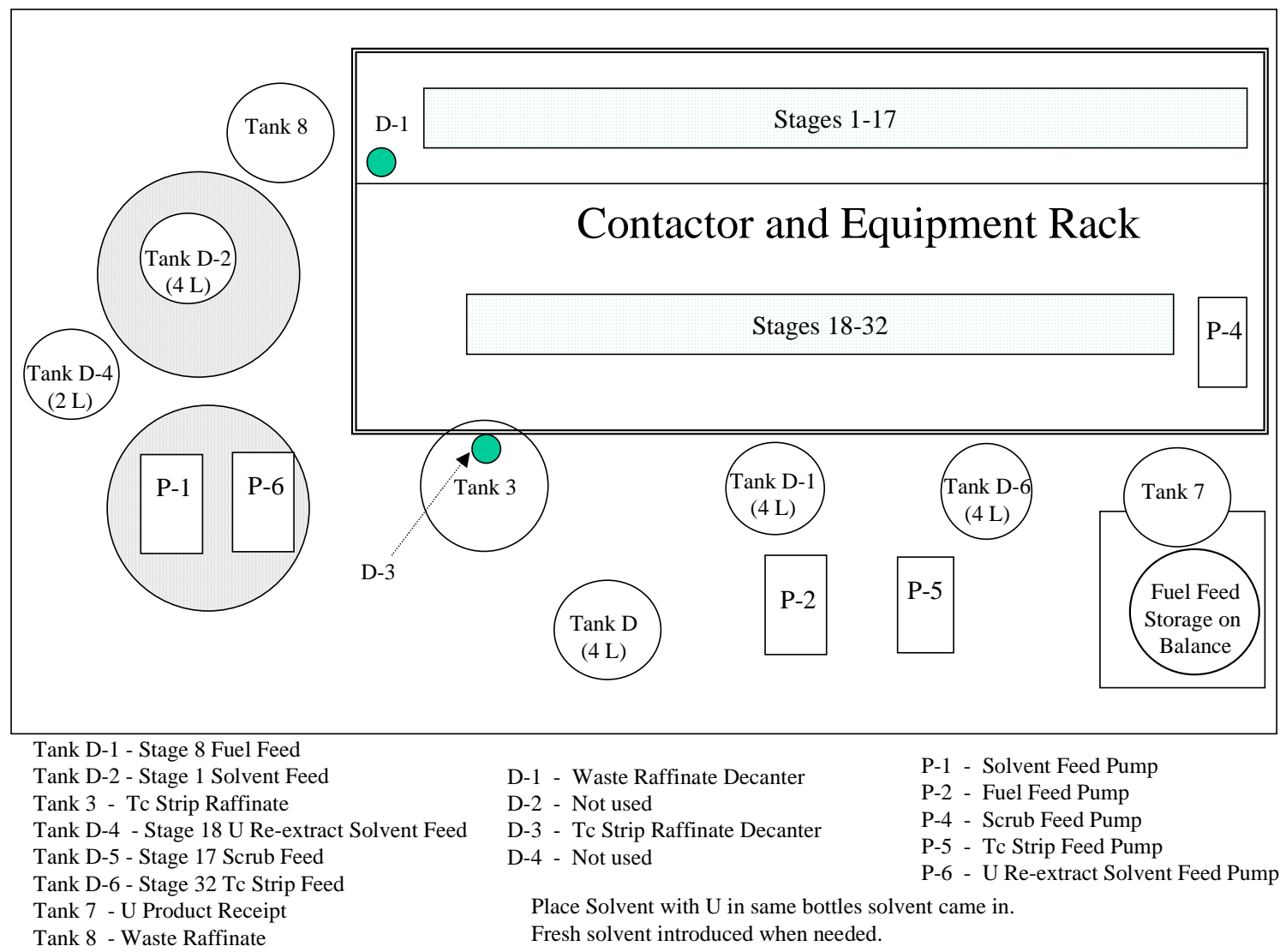

Figure 3: UREX Equipment Arrangement

Feed tanks were 2 or 4-L capacity graduated cylinders with a burette attached to the side that can be isolated from the main tank by a stopcock when checking flow rates (see Figure 4). The inlet to the pump was attached to the standpipe that is shown behind the burette. Manual adjustment of the feed pump speeds occurred as necessary based on the flow measurements. In general, the solvent flow rate held constant once set at the desired flow rate. Most differences can be attributed to the difficulty in observing the meniscus in the side arm due to pulsation from the FMI pumps. The uncertainty of the readings was estimated to be +/- $5 \%$. The uncertainty of the readings for the feed and Tc strip was lower because the meniscus did not pulsate as much.

To initiate an experiment, the rotors were started and then flow of the aqueous streams, surrogate feed ( $\left.1 \mathrm{M} \mathrm{HNO}_{3}\right)$, scrub (0.47 M AHA in $\left.0.3 \mathrm{M} \mathrm{HNO}_{3}\right)$, and strip $\left(6 \mathrm{M} \mathrm{HNO}_{3}\right)$, was initiated. Aqueous flows were continued until flow was observed exiting into the raffinate and Tc product decanters. At this point, the solvent and $U$ re-extract pumps were started and operated until organic was observed exiting stage 32. The feed tank was then emptied of $1 \mathrm{M} \mathrm{HNO}_{3}$ and the feed solution pumped into the tank with a transfer pump. 
WSRC-TR-2002-00444

Revision 0

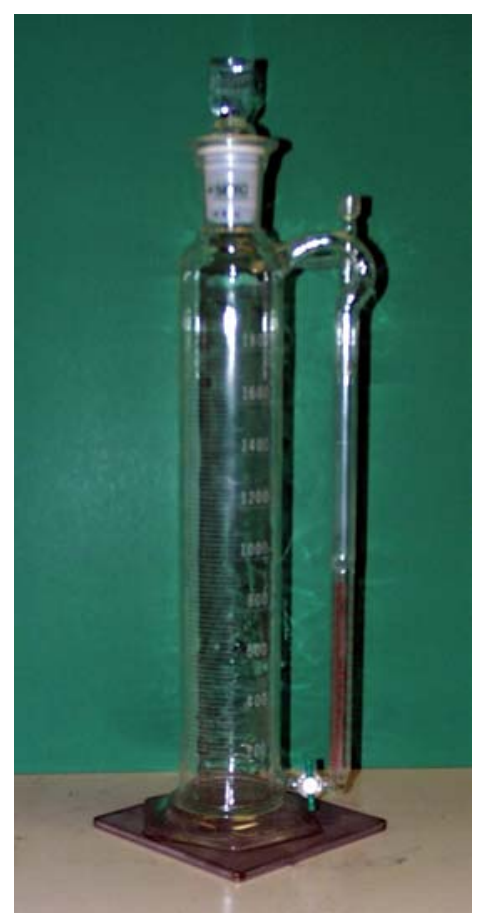

Figure 4: Feed Tank for UREX Solvent Extraction Tests

During tests, the following items were monitored. The frequency at which these items were monitored is shown in parentheses.

- Motor rotation (15 minutes)

- Liquid in standpipes (15 minutes)

- Feed and collection tank levels (30 minutes).

- Decanter levels (1 hour)

- Temperature trends (1 hour)

- Measured process stream flow rates (1 hour or as needed).

Samples were collected by placing sample bottles under the outlet points of the continuously flowing streams. Samples were taken hourly during the simulant and first two tests and every two hours during the third test.

At the end of each test, researchers stopped the motor rotation and feed pumps simultaneously to minimize disruption of the contents of each stage for the post-test stage samples. Drain valves on each contactor stage allowed removal of each stage's contents at the end of the test. 
WSRC-TR-2002-00444

Revision 0

\section{Solvent Extraction Tests}

\section{Hydraulic Testing}

Hydraulic tests were performed with the contactor system to determine that the desired flow rates would result in stable operation. Both the feed and Tc strip solutions were $1 \mathrm{M}$ $\mathrm{HNO}_{3}$ instead of the flow sheet solutions of $290 \mathrm{~g} / \mathrm{L} \mathrm{U}$ in $1 \mathrm{M} \mathrm{HNO}_{3}$ and $6 \mathrm{M} \mathrm{HNO}_{3}$, respectively. This was done to reduce the volume of waste produced and should be conservative relative to hydraulic operation due to the lower density of both solutions compared to the actual feed solutions. The scrub solution was $0.3 \mathrm{M} \mathrm{HNO}_{3}$. The planned conditions for the tests were:

Feed $-5.7 \mathrm{~mL} / \mathrm{min}$

Solvent $-20 \mathrm{~mL} / \mathrm{min}$

Scrub $-3.3 \mathrm{~mL} / \mathrm{min}$

Tc Strip - $20.0 \mathrm{~mL} / \mathrm{min}$

Tc Re-extract $-5.5 \mathrm{~mL} / \mathrm{min}$

However, a short time after start of Tc re-extract flow, the decanter filled with solvent indicating the strip contactor stages would not operate at the combined flow rate of 45.5 $\mathrm{mL} / \mathrm{min}$. Failure to operate at this total flow rate was unexpected since ANL had used similar flows during a simulate test done earlier. Operation of the rotors was examined and stage 21 was found to be suspect. The stage 21 rotor was subsequently replaced. The contactors still did not operate correctly so all flow rates were lowered by $25 \%$ to 4.28 , $15.0,2.48,15.00$, and $4.13 \mathrm{~mL} / \mathrm{min}$, respectively. The contactor hydraulics worked well so the flows were increased to $4.85,17.0,2.81,17.0$, and $4.68 \mathrm{~mL} / \mathrm{min}$, respectively. The contactors were operated again for several hours and then the $U$ re-extract flow was increased from 4.68 to $5.53 \mathrm{~mL} / \mathrm{min}$. No hydraulic problems were observed at these flow rates and no further hydraulic testing was done.

\section{Simulant Test}

A test of the UREX flowsheet was done with simulated feed solution prior to the first test with Dresden fuel solution. Two liters of simulant solution were prepared by dissolving $684 \mathrm{~g}$ of $\mathrm{U}_{3} \mathrm{O}_{8}$ (depleted $\mathrm{U}$ ) in $1.5 \mathrm{~L}$ of $5 \mathrm{M} \mathrm{HNO}_{3}$ containing $1.2 \mathrm{~g}$ of sodium perrhenate $\left(\mathrm{NaReO}_{4}\right.$, as a non-radioactive surrogate for Tc). Water was added to increase the volume to $1875 \mathrm{~mL}$ prior to adding $108 \mathrm{~mL}$ of $40 \mathrm{~g} / \mathrm{L} \mathrm{Pu}$ nitrate in $1 \mathrm{M} \mathrm{HNO}_{3}$. The solution was then diluted to $2 \mathrm{~L}$ with water. The $\mathrm{Pu}$ was weapons grade material, which has a different isotopic composition than the Dresden fuel $\mathrm{Pu}$. Analytical results on the feed solution showed $287 \mathrm{~g} / \mathrm{L} \mathrm{U}, 1.03 \mathrm{M}$ free acid, $0.4 \mathrm{~g} / \mathrm{L} \mathrm{Re}$, and $2.13 \mathrm{~g} / \mathrm{L} \mathrm{Pu}$.

\section{Dresden Fuel Solution Tests}

Three tests of the UREX process were made with the Dresden fuel feed. The flow rates and concentrations of AHA and acid were determined from calculations with the AMUSE computer program by ANL personnel. In each test, the flow rates were measured at the start of feed flow, 45 minutes after starting and every 60 minutes thereafter. Samples of all 3 end streams were taken every hour after the first 2 hours of operation. During the first 2 hours of operation, the waste raffinate was sampled every 30 minutes, the Tc product and U-loaded solvent streams were sampled at 1, 1.5, and 2 
WSRC-TR-2002-00444

Revision 0

hours. The organic $U$ product samples were stripped with sodium carbonate and re-acidified prior to submitting for analysis. The treatment for stripping and reacidification resulted in a dilution by a factor of 5 for samples submitted for analysis except for $U$ where the dilution was by a factor of 10 . Waste raffinate samples were diluted (1000-5000 times) as needed to allow removal from the shielded cell for analyses. Samples from stages 1, 3, 5, 7, 9, 11, 13, 15, 17, 18, 20, 22, 24, 26, 28, 30 and 32 were collected for later separation. The stage samples were placed in separatory funnels to allow the phases to completely separate prior to sampling for subsequent analysis.

\section{Analytical Methods}

All analyses were done by the Analytical Development Section at SRTC. Uranium product analyses were done spectrophotometrically on solutions adjusted to $1 \mathrm{M} \mathrm{HNO}_{3}$ and 1-10 g/L U. ${ }^{11}$ Lower concentrations of $\mathrm{U}$ were done either by inductively coupled plasma mass spectroscopy (ICP-MS) or laser fluorescence spectroscopy. Analyses of general elemental concentrations were done by inductively coupled plasma emission spectroscopy. Analyses for ${ }^{90} \mathrm{Sr}$ required separation prior to beta counting using liquid scintillation. Plutonium analyses were done by extraction with thenoyltrifluoroacetylacetone in hexane followed by alpha pulse height analysis. A second sample was spiked with $\mathrm{Pu}-239$ and the same extraction and counting to determine the recovery efficiency. Technetium analyses were done by separation with ion exchange and beta counting.

\section{Results and Discussion}

\section{UREX Solvent Extraction Testing}

\section{Simulant Test}

Prior to using dissolved Dresden fuel solution, a test was made with solution simulating the expected acid, $\mathrm{U}, \mathrm{Pu}$, and $\mathrm{Tc}$ (using Re as a surrogate for Tc) concentrations in the Dresden fuel feed solution. The simulant test lasted for six hours. Table II shows the flowsheet and actual flow rates during the test. Note that the feed and scrub flow rates varied more than the other flow rates. The range for the solvent is probably the variability of the flow measurement. Note that flow rates of all aqueous streams appear to be slightly lower than the desired flows.

Figure 5 shows the flow rate ratios during the test. Note that the flow rate ratios are close to the desired ratios (the straight lines on the chart) except for the solvent to feed plus scrub ratio. That ratio was high because the scrub flow rate was low during much of the test. The low scrub flow is also shown in the scrub to feed ratio where the flow ratios are low until about 3.5 hours into the test. 
WSRC-TR-2002-00444

Revision 0

Table II: Flow Rates for UREX Simulant Test

\begin{tabular}{|l|l|l|}
\hline Stream & Flowsheet, $\mathrm{mL} / \mathrm{min}$ & $\begin{array}{l}\text { Actual Flow rate } \\
\text { Range, } \mathrm{mL} / \mathrm{min}\end{array}$ \\
\hline Extractant & 17.0 & $16.8-17.0$ \\
\hline Feed & 4.85 & $4.65-4.79$ \\
\hline Scrub & 2.81 & $2.50-2.76$ \\
\hline Tc Strip & 17.0 & $16.75-16.85$ \\
\hline U Re-extract & $5.50-6.00$ & 5.92 \\
\hline
\end{tabular}

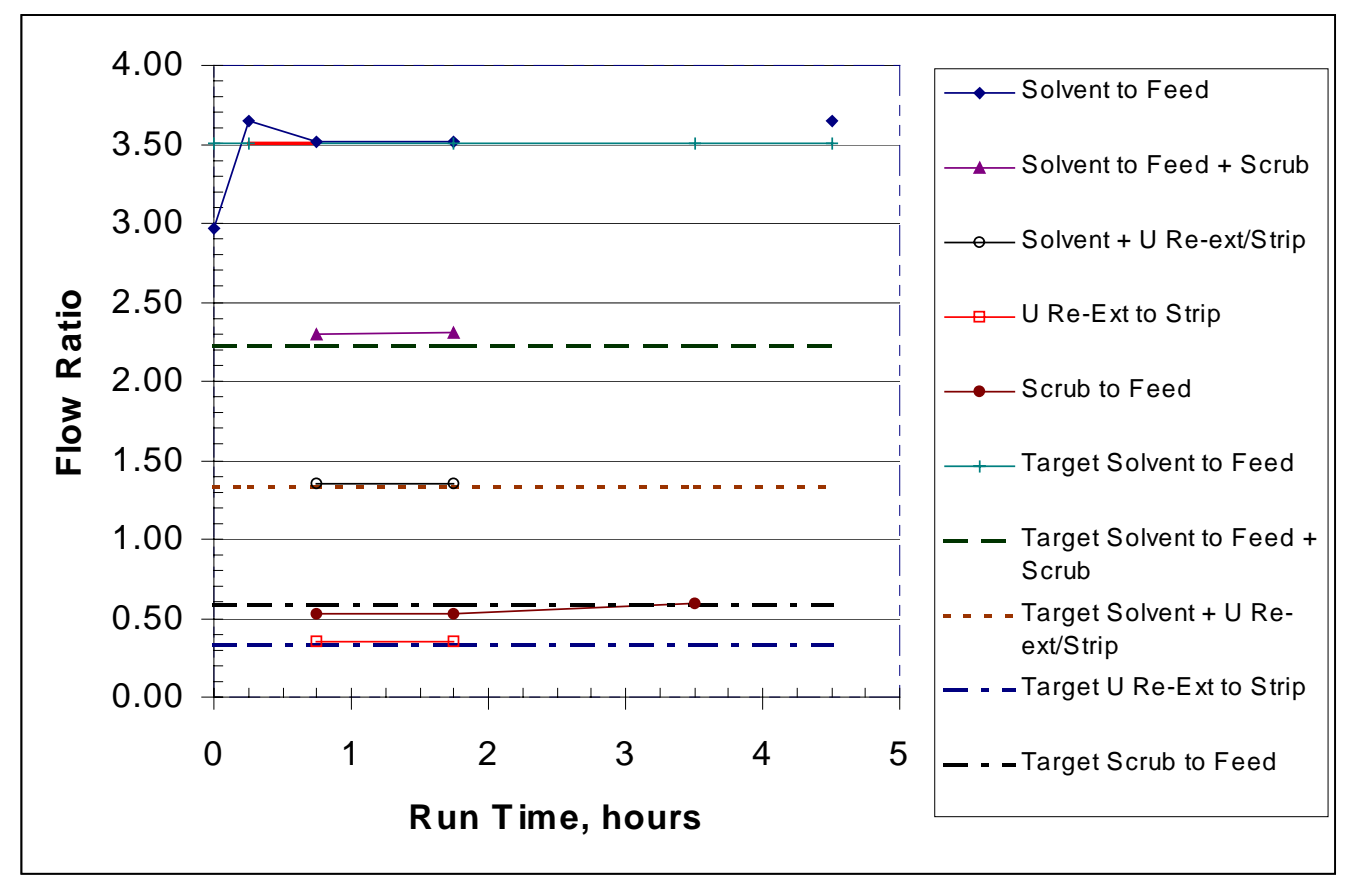

Figure 5: Simulant Test Flow Ratios

The test ran well hydraulically with $<1 \%$ other phase contamination of any stream. $\mathrm{Pu}$ was rejected to the waste and $\mathrm{U}$ was recovered in the U product stream (see Table III). U was low in the Tc product and raffinate streams. Note that the $U$ in the raffinate is well below $0.01 \%$ of that in the feed. However, the $\mathrm{U}$ in the Tc product stream would be higher than the $0.01 \%$ of the Tc concentration. The Pu decontamination factor for the $\mathrm{U}$ product is 137,000 , which is high enough to produce a non-TRU product. However, Re chemistry is apparently different enough that the Re mostly went to the waste raffinate along with $\mathrm{Pu}$; some went to the $\mathrm{U}$ product stream rather than stripping into the $\mathrm{Tc}$ product stream. Overall the simulant test showed the flowsheet could be operated hydraulically and the U product was not a TRU waste. 
WSRC-TR-2002-00444

Revision 0

Table III: Mass Balance for UREX Simulant Test

\begin{tabular}{|l|l|l|l|l|}
\hline Stream & $\begin{array}{l}\text { Time of } \\
\text { Operation, hrs }\end{array}$ & $\% \mathrm{U}$ & $\% \mathrm{Pu}$ & $\% \mathrm{Re}$ \\
\hline U Product & 0 & & & \\
\hline & 1 & 76.4 & $6.47 \mathrm{E}-04$ & 2.34 \\
\hline & 1.5 & 96.1 & $7.59 \mathrm{E}-04$ & 2.92 \\
\hline & 3 & 91.1 & $6.67 \mathrm{E}-05$ & 2.46 \\
\hline & 4 & 100.7 & $4.06 \mathrm{E}-04$ & 2.83 \\
\hline & 5 & 101.3 & $5.53 \mathrm{E}-03$ & 2.98 \\
\hline & 6 & 101.7 & $7.30 \mathrm{E}-04$ & 2.61 \\
\hline Tc Product & 0 & & & \\
\hline & 1 & No Data & $1.00 \mathrm{E}-04$ & 0.36 \\
\hline & 1.5 & No Data & $7.08 \mathrm{E}-05$ & 0.49 \\
\hline & 3 & No Data & $6.19 \mathrm{E}-05$ & 0.31 \\
\hline & 4 & No Data & $6.39 \mathrm{E}-05$ & 0.15 \\
\hline & 5 & $1.22 \mathrm{E}-02$ & $1.20 \mathrm{E}-04$ & 0.09 \\
\hline & 6 & $3.65 \mathrm{E}-02$ & $4.03 \mathrm{E}-04$ & 0.09 \\
\hline & 0 & & & \\
\hline Waste Raffinate & 1 & No Data & 37.5 & 25.56 \\
\hline & 1.5 & No Data & 95.8 & 70.75 \\
\hline & 3 & No Data & 114.5 & 93.51 \\
\hline & 4 & No Data & 115.6 & 105.20 \\
\hline & 5 & $9.67 \mathrm{E}-05$ & 106.1 & 101.08 \\
\hline & 6 & $9.13 \mathrm{E}-05$ & 103.9 & 98.75 \\
\hline
\end{tabular}

\section{UREX Tests with Dresden Fuel Solution}

\section{UREX Hot Demonstration Test 1}

Three tests were done with the 13 liters of solution obtained from dissolution of Dresden fuel. In the first test, inadequate mixing of the dissolver solution during dilution resulted in the feed solution being much higher in $\mathrm{U}(466 \mathrm{~g} / \mathrm{L})$ and acid $(\sim 1.4 \mathrm{M})$ than the flowsheet is designed to process. In addition, there was an accidental cessation of feed flow during the test and some other operational problems. Temperatures measured during the test varied as shown below.

Stages 1-15: $20-28{ }^{\circ} \mathrm{C}$

Stages 16-17: $26-33{ }^{\circ} \mathrm{C}$

Stages 18-32: $26-37^{\circ} \mathrm{C}$

The temperature in the extraction section should be $25^{\circ} \mathrm{C}$ or less to ensure the extraction of Tc. Some of the scrub stages were above the desired temperature of $25{ }^{\circ} \mathrm{C}$ so it was possible that some Tc could be lost to the raffinate stream. The high scrub section temperatures were present in all the tests because the last scrub stages have no cooling other than the organic solvent containing the $\mathrm{U}$. As a result of the problems encountered, analyses were not completed. However, some promising results were observed from the limited analyses. The test showed better control of the flow rate ratios than in the simulant test (see Figure 6). 
Better control of flows and flow ratios gave relatively good decontamination of the $\mathrm{U}$ and Tc product solutions. The results of analyses during the test are shown in Table VI. Note that the $U$ concentration in the $U$ product should have been almost $90 \mathrm{~g} / \mathrm{L}$. However, little of the $U$ appears to be in the raffinate. Almost none appears in the Tc product as expected with $6 \mathrm{M} \mathrm{HNO}_{3}$ in the strip solution. There could have been some accumulation of $U$ in the contactors. However, a calculation of the quantity of $U$ that could be in the contactors is <50 grams (based on the volume per stage of $30 \mathrm{~mL}$ ) relative to a 150-200 $\mathrm{g} \mathrm{U}$ discrepancy in the mass balance. It is more likely that there is a dilution error during stripping of the $\mathrm{U}$ from the solvent. The $\mathrm{U}$ product meets low level waste criteria for Tc, $\mathrm{Cs}, \mathrm{Pu}-241$, and $\mathrm{Sr}$, based on the data at the end of the test.

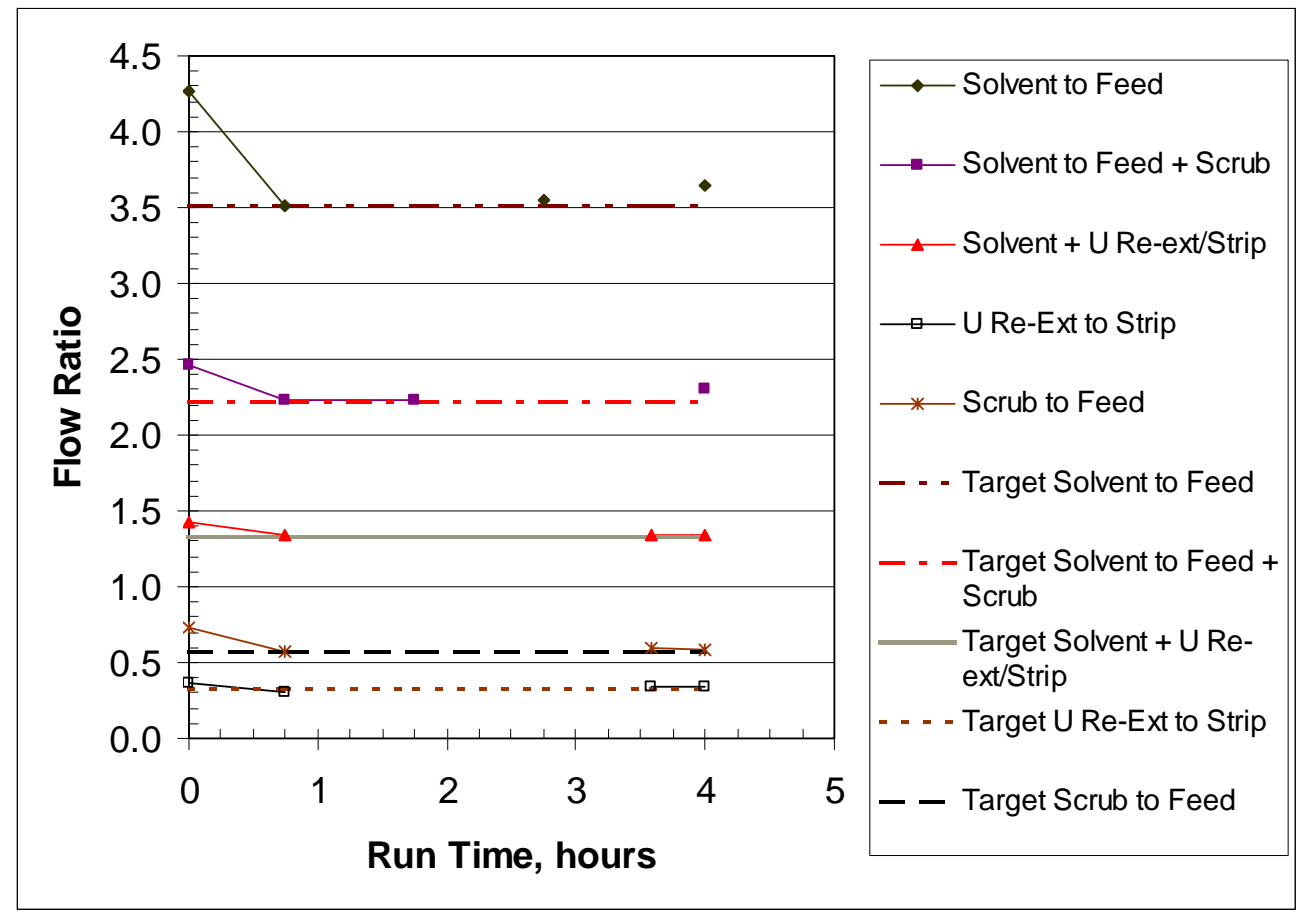

Figure 6: Flow Ratios for UREX Test 1

Table IV: End Stream Analyses from UREX Hot Demonstration Test 1

\begin{tabular}{|l|c|c|c|c|c|c|c|c|}
\hline \multirow{4}{*}{ Stream } & Time of & $\mathbf{U}$ & $\mathbf{P u}$ & $\mathbf{A m}$ & $\mathbf{C m}$ & $\mathbf{T c}$ & $\mathbf{C s}$ & $\mathbf{S r}$ \\
\cline { 2 - 9 } & Operation & $\mathrm{g} / \mathrm{L}$ & $\mathrm{d} / \mathrm{m} / \mathrm{mL}$ & $\mathrm{d} / \mathrm{m} / \mathrm{mL}$ & $\mathrm{d} / \mathrm{m} / \mathrm{mL}$ & $\mathrm{d} / \mathrm{m} / \mathrm{mL}$ & $\mathrm{d} / \mathrm{m} / \mathrm{mL}$ & $\mathrm{d} / \mathrm{m} / \mathrm{mL}$ \\
\hline \multirow{4}{*}{ U Product } & 0 & 13.1 & $2.60 \mathrm{E}+03$ & $\mathrm{ND}$ & $\mathrm{ND}$ & $<2.1 \mathrm{E}+03$ & $1.30 \mathrm{E}+03$ & $8.10 \mathrm{E}+03$ \\
\cline { 2 - 10 } & 1 & 36.2 & $1.89 \mathrm{E}+03$ & $2.81 \mathrm{E}+03$ & 189 & $<2.7 \mathrm{E}+03$ & $3.30 \mathrm{E}+04$ & $<5.2 \mathrm{E}+03$ \\
\cline { 2 - 9 } & 1.5 & 33.7 & $2.19 \mathrm{E}+03$ & $1.55 \mathrm{E}+03$ & 179 & $<1.2 \mathrm{E}+04$ & $2.34 \mathrm{E}+04$ & $<5.2 \mathrm{E}+03$ \\
\cline { 2 - 9 } & 2 & 35.5 & $1.34 \mathrm{E}+03$ & $1.45 \mathrm{E}+03$ & 292 & $<2.1 \mathrm{E}+03$ & $1.72 \mathrm{E}+04$ & $<5.2 \mathrm{E}+03$ \\
\cline { 2 - 9 } & 6 & 31.9 & $1.14 \mathrm{E}+04$ & $9.05 \mathrm{E}+03$ & 465 & $<1.3 \mathrm{E}+03$ & $1.09 \mathrm{E}+04$ & $<5.2 \mathrm{E}+03$ \\
\hline Tc Product & 0 & $\mathrm{ND}$ & $5.32 \mathrm{E}+02$ & $4.79 \mathrm{E}+02$ & 165 & $2.20 \mathrm{E}+03$ & $2.68 \mathrm{E}+05$ & $3.57 \mathrm{E}+03$ \\
\cline { 2 - 9 } & 6 & 0.0045 & $4.54 \mathrm{E}+02$ & $4.57 \mathrm{E}+02$ & 48 & $1.08 \mathrm{E}+06$ & $6.90 \mathrm{E}+04$ & $6.35 \mathrm{E}+03$ \\
\hline \multirow{2}{*}{$\begin{array}{c}\text { Waste } \\
\text { Raffinate }\end{array}$} & 0 & $\mathrm{ND}$ & $7.94 \mathrm{E}+07$ & $\mathrm{ND}$ & $\mathrm{ND}$ & $1.04 \mathrm{E}+04$ & $1.39 \mathrm{E}+06$ & $1.01 \mathrm{E}+06$ \\
\cline { 2 - 9 } & 6 & 0.227 & $1.14 \mathrm{E}+09$ & $1.02 \mathrm{E}+09$ & $\mathrm{ND}$ & $3.07 \mathrm{E}+05$ & $1.02 \mathrm{E}+10$ & $1.52 \mathrm{E}+10$ \\
\hline
\end{tabular}

ND - No Data 
However, the TRU isotope alpha is almost three times higher than the limit of $100 \mathrm{nCi} / \mathrm{g}$ $\mathrm{U}$. If the $\mathrm{U}$ concentration in the product had been the expected $90 \mathrm{~g} / \mathrm{L}$, the TRU limit would be exceeded by only $10 \%$. The Pu losses to the $\mathrm{U}$ and Tc product streams totals $<0.01 \%$ of the $\mathrm{Pu}$ in the feed. This result confirms that $>99.9 \%$ of the $\mathrm{Pu}$ was in the raffinate stream meeting one of the goals of the process. Total U losses to the Tc product and raffinate streams was $0.08 \%$ of the $\mathrm{U}$. Although this is higher than expected, it still meets the goal of $>99.9 \%$ recovery of $U$.

\section{UREX Hot Demonstration Test 2}

The second UREX test was run for 6 hours with stable hydraulic operation and few operational problems. Temperatures measured during the test varied as shown below.

Stages 1-15: $17-28{ }^{\circ} \mathrm{C}$

Stages 16-17: $26-32{ }^{\circ} \mathrm{C}$

Stages 18-32: $27-35^{\circ} \mathrm{C}$

During operation, personnel noted that the raffinate in the decanter was very dark in color as expected for the Pu AHA complex, which is a dark red. The color of the Fe AHA complex is a method for analysis of AHA concentration in solution.

Figure 7 shows the flow ratios over the time of the test. Note that the flow ratios did not match as well as in test 1 . The solvent to feed ratio was high, which would lead to lower saturation of the solvent and possibly lower decontamination of product streams.

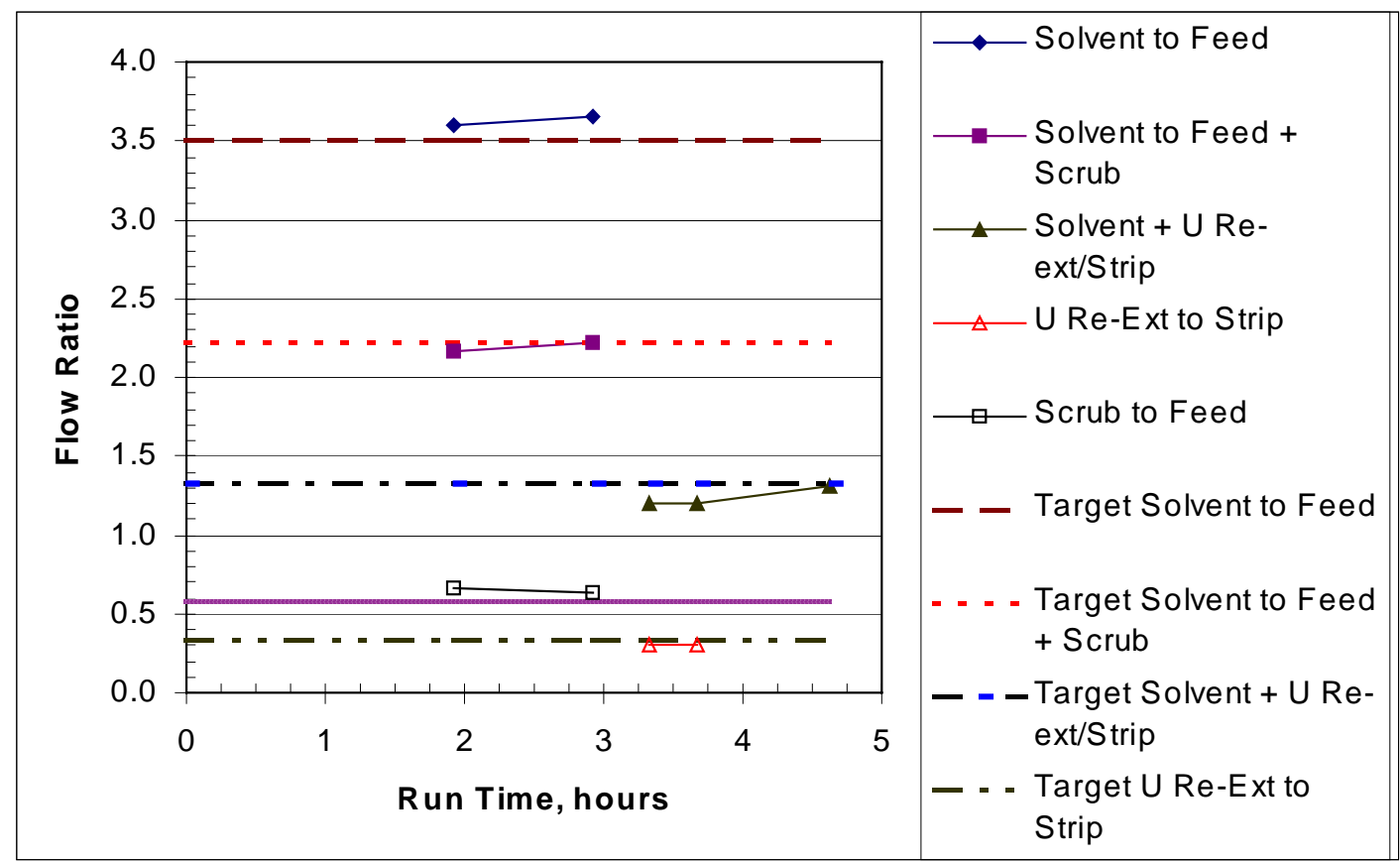

Figure 7: UREX Test 2 Flow Rate Ratios

Table V shows the analytical results for test 2 and Table VI shows the mass balances for the test. The acid concentration in the Tc product solution after 6 hours of operation was measured to be $5.21 \mathrm{M}$. The data show that $\mathrm{U}$ almost reached steady state concentration 
in the $\mathrm{U}$ product after one hour of operation and was at steady state by 3 hours. That does not appear to be the case for the other nuclides. Pu and Am data seem to go up and down.

Table V : Analytical Results for Test 2

\begin{tabular}{|l|c|c|c|c|c|c|c|}
\hline \multirow{4}{*}{ Stream } & Time of & $\mathbf{U}$ & $\mathbf{P u}$ & $\mathbf{A m}$ & $\mathbf{C s}$ & $\mathbf{T c}$ & $\mathbf{S r}$ \\
\cline { 2 - 8 } & Operation & $\mathrm{g} / \mathrm{L}$ & $\mathrm{d} / \mathrm{m} / \mathrm{mL}$ & $\mathrm{d} / \mathrm{m} / \mathrm{mL}$ & $\mathrm{d} / \mathrm{m} / \mathrm{mL}$ & $\mathrm{d} / \mathrm{m} / \mathrm{mL}$ & $\mathrm{d} / \mathrm{m} / \mathrm{mL}$ \\
\hline U Product & 0 & 3.9 & $4.12 \mathrm{E}+04$ & $1.16 \mathrm{E}+04$ & $7.90 \mathrm{E}+04$ & $2.11 \mathrm{E}+03$ & $1.02 \mathrm{E}+04$ \\
\cline { 2 - 8 } & 1 & 51.2 & $4.43 \mathrm{E}+03$ & $2.85 \mathrm{E}+03$ & $6.05 \mathrm{E}+03$ & $2.72 \mathrm{E}+03$ & $3.84 \mathrm{E}+03$ \\
\cline { 2 - 8 } & 3 & 54.5 & $6.01 \mathrm{E}+03$ & $0.00 \mathrm{E}+00$ & $8.98 \mathrm{E}+03$ & $1.15 \mathrm{E}+04$ & $3.85 \mathrm{E}+03$ \\
\cline { 2 - 8 } & 4 & 53.7 & $1.18 \mathrm{E}+04$ & $1.53 \mathrm{E}+04$ & $1.17 \mathrm{E}+04$ & $2.07 \mathrm{E}+03$ & $3.85 \mathrm{E}+03$ \\
\hline Tc Product & 6 & 55.1 & $3.02 \mathrm{E}+03$ & $5.07 \mathrm{E}+03$ & $1.67 \mathrm{E}+04$ & $1.29 \mathrm{E}+03$ & $5.00 \mathrm{E}+03$ \\
\cline { 2 - 8 } & 2 & $<4.5 \mathrm{E}-03$ & NA & NA & $1.53 \mathrm{E}+05$ & $2.25 \mathrm{E}+04$ & $2.10 \mathrm{E}+04$ \\
\cline { 2 - 8 } & 3 & $<4.5 \mathrm{E}-03$ & $2.41 \mathrm{E}+03$ & NA & $1.28 \mathrm{E}+05$ & $1.58 \mathrm{E}+06$ & $1.46 \mathrm{E}+04$ \\
\cline { 2 - 8 } & 4 & $<4.5 \mathrm{E}-03$ & $8.41 \mathrm{E}+03$ & $5.00 \mathrm{E}+03$ & $3.34 \mathrm{E}+05$ & $1.81 \mathrm{E}+06$ & $1.02 \mathrm{E}+05$ \\
\cline { 2 - 8 } & 6 & $7.9 \mathrm{E}-05$ & $4.67 \mathrm{E}+03$ & $7.53 \mathrm{E}+03$ & $3.93 \mathrm{E}+05$ & $1.45 \mathrm{E}+06$ & $1.11 \mathrm{E}+05$ \\
\hline Waste & 1 & NA & $6.72 \mathrm{E}+08$ & $8.79 \mathrm{E}+08$ & $1.77 \mathrm{E}+10$ & $1.64 \mathrm{E}+06$ & NA \\
\cline { 2 - 8 } Raffinate & 2 & NA & $8.55 \mathrm{E}+08$ & $6.57 \mathrm{E}+08$ & $1.26 \mathrm{E}+10$ & $5.84 \mathrm{E}+06$ & $9.78 \mathrm{E}+09$ \\
\cline { 2 - 8 } & 3 & NA & $1.04 \mathrm{E}+09$ & NA & $1.93 \mathrm{E}+10$ & $5.72 \mathrm{E}+06$ & $1.30 \mathrm{E}+10$ \\
\cline { 2 - 8 } & 4 & 0.0026 & $7.57 \mathrm{E}+08$ & NA & $1.68 \mathrm{E}+10$ & $1.45 \mathrm{E}+06$ & $1.94 \mathrm{E}+10$ \\
\cline { 2 - 8 } & 6 & 0.0297 & $7.97 \mathrm{E}+08$ & $7.50 \mathrm{E}+08$ & $1.89 \mathrm{E}+10$ & $2.90 \mathrm{E}+06$ & $1.47 \mathrm{E}+10$ \\
\hline
\end{tabular}

Table VI: Mass Balance Results for Test 2

\begin{tabular}{|c|c|c|c|c|c|c|c|}
\hline \multirow[b]{2}{*}{ Stream } & \multirow{2}{*}{$\begin{array}{c}\text { Time of } \\
\text { Operation }\end{array}$} & $\mathbf{U}$ & $\mathbf{P u}$ & $\mathrm{Am}$ & Cs & Tc & $\mathbf{S r}$ \\
\hline & & $\%$ & $\%$ & $\%$ & $\%$ & $\%$ & $\%$ \\
\hline \multirow[t]{5}{*}{ U Product } & 0 & 6 & $1.87 \mathrm{E}-02$ & $5.13 \mathrm{E}-03$ & $1.81 \mathrm{E}-03$ & $<0.17$ & 2.24E-04 \\
\hline & 1 & 84 & $2.01 \mathrm{E}-03$ & $1.26 \mathrm{E}-03$ & $1.38 \mathrm{E}-04$ & $<0.21$ & $<.84 \mathrm{E}-05$ \\
\hline & 3 & 90 & $2.76 \mathrm{E}-03$ & NA & $2.08 \mathrm{E}-04$ & $<0.91$ & $<8.5 \mathrm{E}-05$ \\
\hline & 4 & 89 & $5.42 \mathrm{E}-03$ & $6.82 \mathrm{E}-03$ & $2.71 \mathrm{E}-04$ & $<.16$ & $<8.5 \mathrm{E}-05$ \\
\hline & 6 & 91 & $1.38 \mathrm{E}-03$ & $2.26 \mathrm{E}-03$ & $3.86 \mathrm{E}-04$ & $<.10$ & $1.11 \mathrm{E}-04$ \\
\hline \multirow[t]{5}{*}{ Tc Product } & 0 & $<6.1 \mathrm{E}-03$ & NA & NA & $2.86 \mathrm{E}-03$ & 1.4 & $3.76 \mathrm{E}-04$ \\
\hline & 2 & $<6.1 \mathrm{E}-03$ & $8.95 \mathrm{E}-04$ & NA & 2.39E-03 & 101 & $2.43 \mathrm{E}-04$ \\
\hline & 3 & $<6.1 \mathrm{E}-03$ & $8.68 \mathrm{E}-03$ & $6.76 \mathrm{E}-03$ & 8.48E-03 & 118 & $3.88 \mathrm{E}-03$ \\
\hline & 4 & $<6.1 \mathrm{E}-03$ & $3.14 \mathrm{E}-03$ & $1.82 \mathrm{E}-03$ & $6.29 \mathrm{E}-03$ & 116 & $1.71 \mathrm{E}-03$ \\
\hline & 6 & $9.8 \mathrm{E}-05$ & $1.61 \mathrm{E}-03$ & $2.52 \mathrm{E}-03$ & $6.82 \mathrm{E}-03$ & 86 & $1.71 \mathrm{E}-03$ \\
\hline \multirow{5}{*}{$\begin{array}{l}\text { Waste } \\
\text { Raffinate }\end{array}$} & 1 & NA & 103 & 131 & 136 & 43 & NA \\
\hline & 2 & NA & 131 & 98 & 97 & 154 & 72 \\
\hline & 3 & NA & 157 & NA & 146 & 148 & 94 \\
\hline & 4 & 0.0014 & 114 & NA & 127 & 38 & 141 \\
\hline & 6 & 0.0161 & 120 & 110 & 143 & 75 & 107 \\
\hline
\end{tabular}

NA - No analysis 
It is unlikely to be contamination because the $\mathrm{Cs}$, $\mathrm{Tc}$ and $\mathrm{Sr}$ data do not show the same effect. The U mass balance is lower than observed in the simulant test, but is within $10 \%$. The difference could be in measurement of the organic flow rates, which pulsed due to the piston pump action. Regardless of the low U mass balance, the U product from this test is lower than Class $\mathrm{C}$ waste for TRU and all fission products demonstrating that the UREX process meets that goal.

In addition, although the mass balance data indicate that less than $99.9 \%$ of the $U$ was recovered, less than $0.1 \%$ of the $\mathrm{U}$ is in the raffinate and Tc product $(0.016 \%)$. Data on $\mathrm{U}$ in the Tc stream is very low at about $1 \mathrm{E}-04 \%$.

The mass balance for the Tc product stream appears to go through a maximum and then decrease again. However, the average of the data from 2 through 6 hours is $105 \%$. The Tc behavior could also be a flow rate problem, but no flow measurements were made over the last four hours of the test. It should be noted that the Tc strip flow rate was high early in the test and efforts were made to reduce the strip flow closer to the desired flow rate of $17.0 \mathrm{~mL} / \mathrm{min}$. The raffinate also shows large amounts of Tc. The problem with the existing data is that the samples had very high very high dilutions $(11,000$ to 27,000$)$ so minor contamination of the samples led to high Tc counts in the samples. The Tc product samples are much more reliable because no dilution was made on those samples prior to analysis. It appears from the average of the Tc product data that the goal of $>95 \%$ Tc recovery was achieved in this test.

The data also show that $0.011 \%$ of the TRU was in the two product streams demonstrating rejection of $>99.9 \%$ of the $\mathrm{Pu}$ to the raffinate. Therefore, this test demonstrated that all the goals for the UREX process were met.

\section{UREX Hot Demonstration Test 3}

The third test was done in two parts, $3 \mathrm{~A}$ and $3 \mathrm{~B}$. Test $3 \mathrm{~A}$ was 8 hours long with flow rates and feed stream flow rate ratios identical to the first two tests. Test $3 \mathrm{~B}$ was run with different flow rates and flow ratios in both extraction and stripping.

Test 3A operated with stable hydraulics and no operational problems. Temperatures measured during the test varied as shown below.

Stages 1-15: $19-28{ }^{\circ} \mathrm{C}$

Stages 16-17: $29.1-36.7^{\circ} \mathrm{C}$

Stages 18-32: $26.5-39.6{ }^{\circ} \mathrm{C}$

The temperatures for stages 16- 32 were measured over the entire time that tests $3 \mathrm{~A}$ and $3 \mathrm{~B}$ were in progress. The temperatures for stages 1-15 were measured during the actual time of the test.

The flow rates of the feed streams were to be the same as for the previous two tests. Table VII shows the flow rates measured during the test $3 \mathrm{~A}$ including the overall average and standard deviation. The feed flow rate was especially stable during the last portion of the test. Overall the standard deviation for three streams is less than $2 \%$. Such deviations are within the measurement error for flow rates. The other two streams had standard 
deviations of $4 \%$ and $6 \%$. The $6 \%$ deviation was for the scrub stream, which is greater deviation than can be accounted for by measurement uncertainty.

Table VII: Flow Rates Measured during Test 3A

\begin{tabular}{|c|c|c|c|c|c|}
\hline $\begin{array}{l}\text { Run } \\
\text { Time, } \\
\text { hours }\end{array}$ & $\begin{array}{c}\text { Solvent } \\
\text { Flow rate, } \\
\mathrm{mL} / \mathrm{min}\end{array}$ & $\begin{array}{l}\text { Feed } \\
\text { Flow } \\
\text { Rate, } \\
\text { mL/min }\end{array}$ & $\begin{array}{c}\text { Scrub } \\
\text { Flow } \\
\text { Rate, } \\
\text { mL/min }\end{array}$ & $\begin{array}{l}\text { Strip } \\
\text { Flow } \\
\text { Rate, } \\
\text { mL/min }\end{array}$ & $\begin{array}{c}\text { URe- } \\
\text { Extract } \\
\text { Flow } \\
\text { Rate, } \\
\text { mL/min }\end{array}$ \\
\hline 0.58 & 16.80 & 4.61 & 2.87 & 17.17 & 5.86 \\
\hline 0.67 & & 4.67 & & & \\
\hline 1.08 & & 4.72 & & & \\
\hline 1.75 & 16.80 & 4.79 & 2.95 & 17.07 & 5.83 \\
\hline 2.75 & 16.60 & 4.83 & 3.36 & 16.96 & 5.23 \\
\hline 3.75 & 16.90 & 4.82 & 3.04 & 17.07 & 5.95 \\
\hline 4.92 & 16.40 & 4.85 & 2.81 & 17.07 & 5.83 \\
\hline 6.17 & 16.80 & 4.82 & 2.95 & 16.75 & 5.88 \\
\hline 7.00 & 17.10 & 4.82 & 2.85 & 17.28 & 5.88 \\
\hline 7.95 & 17.30 & 4.85 & 2.99 & 17.07 & 5.87 \\
\hline Average & 16.84 & 4.78 & 2.98 & 17.05 & 5.79 \\
\hline Std Dev & 0.28 & 0.08 & 0.17 & 0.15 & 0.23 \\
\hline
\end{tabular}

Error! Not a valid link.

Figure 8: Flow Ratios for Test 3A

Figure 8 shows the flow ratios over the time of the test. The solvent to feed ratio appears to vary around the target value. The solvent to feed plus scrub flow ratio is lower than the target due to the higher than desired scrub flow during much of the test. The higher scrub flow is also apparent in the scrub to feed ratio being higher than the target. The higher scrub flow rate gave higher decontamination for fission products and TRU than observed in the previous tests.

Table VIII shows the analytical results for test $3 \mathrm{~A}$ and Table IX shows the mass balances for the test.

Table VIII: Analytical Data for Test 3A 
WSRC-TR-2002-00444

Revision 0

\begin{tabular}{|c|c|c|c|c|c|c|c|c|}
\hline \multirow[b]{2}{*}{ Stream } & \multirow{2}{*}{$\begin{array}{c}\text { Run } \\
\text { Time }\end{array}$} & $\overline{\mathbf{U}}$ & $\mathbf{P u}$ & Am & $\mathbf{C m}$ & Tc & Cs & $\mathrm{Sr}$ \\
\hline & & $\mathrm{g} / \mathrm{L}$ & $\mathrm{d} / \mathrm{m} / \mathrm{mL}$ & $\mathrm{d} / \mathrm{m} / \mathrm{mL}$ & $\mathrm{d} / \mathrm{m} / \mathrm{mL}$ & $\mathrm{d} / \mathrm{m} / \mathrm{mL}$ & $\mathrm{d} / \mathrm{m} / \mathrm{mL}$ & $\mathrm{d} / \mathrm{m} / \mathrm{mL}$ \\
\hline \multirow[t]{5}{*}{ U Product } & 0 & 30.3 & $8.31 \mathrm{E}+03$ & $7.93 \mathrm{E}+03$ & $2.03 \mathrm{E}+03$ & $\mathrm{NA}$ & $1.46 \mathrm{E}+04$ & $1.67 \mathrm{E}+03$ \\
\hline & 2 & 58.9 & $6.68 \mathrm{E}+03$ & $4.55 \mathrm{E}+02$ & $1.17 \mathrm{E}+02$ & NA & $2.31 \mathrm{E}+04$ & $3.35 \mathrm{E}+03$ \\
\hline & 4 & 12.6 & $2.69 \mathrm{E}+03$ & $4.30 \mathrm{E}+02$ & $1.10 \mathrm{E}+02$ & NA & $1.08 \mathrm{E}+04$ & $6.70 \mathrm{E}+03$ \\
\hline & 6 & 62.7 & $8.60 \mathrm{E}+02$ & $3.70 \mathrm{E}+02$ & $9.49 \mathrm{E}+01$ & NA & $2.34 \mathrm{E}+03$ & $3.35 \mathrm{E}+03$ \\
\hline & 8 & 61.8 & $1.11 \mathrm{E}+03$ & $1.09 \mathrm{E}+03$ & $2.79 \mathrm{E}+02$ & NA & $1.66 \mathrm{E}+03$ & $3.35 \mathrm{E}+03$ \\
\hline \multirow[t]{5}{*}{ Tc Product } & 0 & NA & $1.50 \mathrm{E}+02$ & NA & NA & $5.88 \mathrm{E}+05$ & $4.56 \mathrm{E}+05$ & NA \\
\hline & 2 & NA & $1.20 \mathrm{E}+02$ & NA & NA & $5.98 \mathrm{E}+05$ & $1.03 \mathrm{E}+05$ & $2.76 \mathrm{E}+03$ \\
\hline & 4 & NA & $4.50 \mathrm{E}+02$ & NA & $\mathrm{NA}$ & $1.34 \mathrm{E}+06$ & $1.28 \mathrm{E}+05$ & $4.08 \mathrm{E}+03$ \\
\hline & 6 & $1.0 \mathrm{E}-05$ & $2.11 \mathrm{E}+02$ & NA & NA & $1.40 \mathrm{E}+06$ & $7.42 \mathrm{E}+04$ & $4.37 \mathrm{E}+03$ \\
\hline & 8 & $1.0 \mathrm{E}-05$ & $8.54 \mathrm{E}+02$ & NA & NA & $1.38 \mathrm{E}+06$ & $5.72 \mathrm{E}+04$ & $2.45 \mathrm{E}+03$ \\
\hline \multirow{2}{*}{$\begin{array}{l}\text { Waste } \\
\text { Raffinate }\end{array}$} & 6 & NA & $1.09 \mathrm{E}+09$ & NA & NA & NA & $\mathrm{NA}$ & $2.39 \mathrm{E}+10$ \\
\hline & 8 & NA & $1.63 \mathrm{E}+09$ & NA & NA & NA & $\mathrm{NA}$ & $2.02 \mathrm{E}+10$ \\
\hline
\end{tabular}

NA - Not Available

Contamination of the $\mathrm{U}$ product from this test is the lowest of any of the tests and far lower than Class $\mathrm{C}$ waste limits for TRU and all fission products. The data demonstrate that the UREX process meets the goal for the $\mathrm{U}$ decontamination. The mass balance for $\mathrm{U}$ is quite good at $97.8 \%$ in the last sample. The decontamination of the $\mathrm{U}$ product from fission products was so good that four liters of the organic was removed from the shielded cell for stripping $U$ in a hood. The dose from that quantity of organic solvent was only $1 \mathrm{mrad} / \mathrm{hr}$, indicating a very low level of gamma activity.

The mass balance for the Tc product stream appears to be poor with a maximum of about $70 \%$ with the last two samples essentially identical. That may be indicative of analytical error in the feed analysis. A second sample was taken, but results are unavailable at this time. The data also show that $0.011 \%$ of the TRU was in the two product streams demonstrating rejection of $>99.9 \%$ of the $\mathrm{Pu}$ to the raffinate. Thus, this test demonstrated that most of the goals for the UREX process can be met. 
Table IX: Mass Balances for Test 3A

\begin{tabular}{|l|c|c|c|c|c|c|c|c|}
\hline Stream & $\begin{array}{c}\text { Run } \\
\text { Time }\end{array}$ & $\begin{array}{c}\text { U } \\
\%\end{array}$ & $\begin{array}{c}\text { Pu } \\
\%\end{array}$ & $\begin{array}{c}\text { Am } \\
\%\end{array}$ & $\begin{array}{c}\text { Cm } \\
\%\end{array}$ & $\begin{array}{c}\text { Tc } \\
\%\end{array}$ & $\begin{array}{c}\text { Cs } \\
\%\end{array}$ & $\begin{array}{c}\text { Sr } \\
\%\end{array}$ \\
\hline \multirow{5}{*}{ U Product } & 2 & 92.1 & $1.81 \mathrm{E}-04$ & $1.92 \mathrm{E}-04$ & $5.75 \mathrm{E}-04$ & NA & $5.00 \mathrm{E}-04$ & $<7.0 \mathrm{E}-05$ \\
\cline { 2 - 9 } & 4 & 19.8 & $1.71 \mathrm{E}-04$ & $1.82 \mathrm{E}-04$ & $5.45 \mathrm{E}-04$ & NA & $2.36 \mathrm{E}-04$ & $1.41 \mathrm{E}-04$ \\
\cline { 2 - 9 } & 6 & 85.8 & $1.29 \mathrm{E}-04$ & $1.37 \mathrm{E}-04$ & $4.09 \mathrm{E}-04$ & NA & $4.43 \mathrm{E}-05$ & $<6.1 \mathrm{E}-05$ \\
\cline { 2 - 9 } & 8 & 97.8 & $4.38 \mathrm{E}-04$ & $4.65 \mathrm{E}-04$ & $1.39 \mathrm{E}-03$ & NA & $3.63 \mathrm{E}-05$ & $<7.1 \mathrm{E}-05$ \\
\hline Tc Product & 2 & NA & $1.35 \mathrm{E}-04$ & NA & NA & 34 & $2.09 \mathrm{E}-03$ & $1.42 \mathrm{E}-04$ \\
\cline { 2 - 9 } & 4 & NA & $3.57 \mathrm{E}-05$ & NA & NA & 75 & $1.67 \mathrm{E}-03$ & $6.34 \mathrm{E}-05$ \\
\cline { 2 - 9 } & 6 & $1.2 \mathrm{E}-05$ & $6.16 \mathrm{E}-05$ & NA & NA & 77 & $1.18 \mathrm{E}-03$ & $6.67 \mathrm{E}-05$ \\
\cline { 2 - 9 } & 8 & $1.2 \mathrm{E}-05$ & $2.53 \mathrm{E}-04$ & NA & NA & 77 & $9.23 \mathrm{E}-04$ & $6.24 \mathrm{E}-05$ \\
\hline \multirow{3}{*}{$\begin{array}{c}\text { Waste } \\
\text { Raffinate }\end{array}$} & 6 & NA & NA & NA & NA & NA & NA & 170 \\
\cline { 2 - 9 } & 8 & NA & 118 & NA & NA & NA & NA & 144 \\
\hline
\end{tabular}

NA - Not Available

Test $3 \mathrm{~B}$ was a continuation of test $3 \mathrm{~A}$ except that the flow rates were changed to provide a higher solvent to feed flow ratio and lower strip and $\mathrm{U}$ re-extraction flows to increase the concentration of $\mathrm{U}$ and $\mathrm{Tc}$ in their respective product streams. The flow rates were changed based on calculations done at CEA with the PAREX computer code by Dr. Pascal Baron and Dr. Binh Dinh. ${ }^{12}$ New flow rates are shown below. Note that the solvent flow rate was the only flow that was held constant.

Table X: Comparison of Baseline Flow Rates and Flow Rates for Test 3B

\begin{tabular}{|l|l|l|}
\hline \multicolumn{1}{|c|}{ Stream } & $\begin{array}{c}\text { Baseline Flows } \\
\text { ML/min }\end{array}$ & $\begin{array}{c}\text { Test 3B Flows } \\
\mathbf{m L} / \mathbf{m i n}\end{array}$ \\
\hline Feed & 4.85 & 4.5 \\
\hline Solvent & 17.0 & 17.0 \\
\hline Scrub & 2.8 & 3.0 \\
\hline Tc Strip & 17.0 & 8.5 \\
\hline U Re-extract & 5.8 & 2.1 \\
\hline
\end{tabular}

The flow ratio of solvent to feed was increased $7.9 \%$. The scrub to feed ratio was increased $15 \%$. The solvent to feed + scrub flow ratio was increased $2 \%$. The Tc strip flow was cut in half and the $U$ re-extract flow was cut by almost a factor of 3 . Thus, the total $\mathrm{U}$ product flow was cut from $\sim 23$ to $\sim 19 \mathrm{~mL} / \mathrm{min}$.

After the last samples for test 3A were taken 8 hours after the start of hot feed, the feed point was changed initially from stage 8 to stage 10 to improve $U$ recovery from the raffinate. Then the new flow rates were established. The change of flow rates took 3 hours to get all flows correct. Table XI shows the flow rates measured with the start time being when the feed was changed to stage 10. About an hour after the flows were adjusted a sample was taken and then another sample was taken two hours later. After the first sample at the new flow rates, the pump to recirculate chilled water to the contactors 
WSRC-TR-2002-00444

Revision 0

was found to be off and the extraction stages had reached $32{ }^{\circ} \mathrm{C}$. It is probable that higher temperatures in the extraction section could lead to higher Tc loss to the raffinate.

Table XI: Flow Rates for Test 3B with Feed in Stage 10

\begin{tabular}{|r|r|r|r|r|r|}
\hline $\begin{array}{c}\text { Run } \\
\text { Time, } \\
\text { hours }\end{array}$ & $\begin{array}{c}\text { Solvent rate, } \\
\text { mL/min }\end{array}$ & $\begin{array}{c}\text { Feed } \\
\text { Flow } \\
\text { Rate, } \\
\mathbf{m L} / \mathbf{m i n}\end{array}$ & $\begin{array}{c}\text { Scrub } \\
\text { Flow } \\
\text { Rate, } \\
\mathbf{m L} / \mathbf{m i n}\end{array}$ & $\begin{array}{c}\text { Strip } \\
\text { Flow } \\
\text { Rate, } \\
\mathbf{m L} / \mathbf{m i n}\end{array}$ & $\begin{array}{c}\text { URe- } \\
\text { Extract } \\
\text { Flow } \\
\text { Rate, } \\
\text { mL/min }\end{array}$ \\
\hline 0.00 & & & & 12.46 & \\
\hline 0.08 & & 4.27 & & & \\
\hline 0.30 & & 4.66 & & & \\
\hline 0.30 & & 4.58 & & & \\
\hline 0.30 & & & & 7.5 & \\
\hline 0.50 & & 4.66 & & 8.9 & \\
\hline 1.00 & & & & 8.9 & 3.57 \\
\hline 1.17 & & & & 8.9 & 2.54 \\
\hline 1.25 & & & 3.04 & 8.9 & 2.53 \\
\hline 1.42 & & & 2.94 & 8.9 & 2.26 \\
\hline 1.47 & & & & 8.9 & 1.97 \\
\hline 1.58 & 17.1 & & & & \\
\hline 2.50 & & 4.53 & 2.91 & 8.90 & 1.75 \\
\hline 2.58 & & & & & 1.83 \\
\hline 2.67 & & & & & 2.07 \\
\hline 3.00 & & 4.53 & 2.13 & & \\
\hline 4.00 & & 4.56 & 2.85 & 8.48 & 2.19 \\
\hline 5.25 & & 4.46 & & & \\
\hline
\end{tabular}

The temperatures of the extraction and initial scrub stages were back to $21-22{ }^{\circ} \mathrm{C}$ by the time the second sample was taken. The remaining temperatures were given earlier in this section.

Immediately after the second set of samples was taken a large amount of solvent was observed in the raffinate decanter indicative of a hydraulic upset. The contactors were shut down, some stages drained and then restarted in an effort to resolve the problem. However, hydraulic upsets continued to occur every several hours. After about 10 hours of intermittent operation, the feed point was changed back to stage 8 and operation restarted. Table XII shows the flow rates during the final period of operation.

Table XII: Flow Rates for Test 3B with Feed in Stage 8

\begin{tabular}{|r|r|r|r|r|r|}
\hline $\begin{array}{c}\text { Run } \\
\text { Time, } \\
\text { hours }\end{array}$ & $\begin{array}{c}\text { Solvent } \\
\text { Flow rate, } \\
\mathbf{m L} / \mathbf{m i n}\end{array}$ & $\begin{array}{c}\text { Feed } \\
\text { Flow } \\
\text { Rate, } \\
\mathbf{m L} / \mathbf{m i n}\end{array}$ & $\begin{array}{c}\text { Scrub } \\
\text { Flow } \\
\text { Rate, } \\
\mathbf{m L} / \mathbf{m i n}\end{array}$ & $\begin{array}{c}\text { Strip } \\
\text { Flow } \\
\text { Rate, } \\
\mathbf{m L} / \mathbf{m i n}\end{array}$ & $\begin{array}{c}\text { URe- } \\
\text { Extract } \\
\text { Flow } \\
\text { RL/min }\end{array}$ \\
\hline 0.00 & 16.9 & 4.56 & 3.29 & 8.69 & 2.13 \\
\hline 1.67 & 17.1 & 4.59 & 3.15 & 8.59 & 2.13 \\
\hline
\end{tabular}


The change appeared to resolve the problem until another hydraulic upset occurred 4 hours after restart. Samples were taken 3 hours and 6.5 hours after returning the feed to stage 8 . The test was ended shortly after the last sample when feed solution was gone. Sampling and the hydraulic upset led to fewer flow rate measurements being taken. The upsets are believed to have been the result of solids precipitating from the feed solution after earlier filtration. Solids were observed in the bottom of the feed tank toward the end of the test. Fine solids could easily be pumped to the contactor since the tank feed outlet is also at the bottom of the tank.

The results of test 3B are shown in Tables XIII through XVI.

Table XIII: Analytical Data for Test 3B with Feed in Stage 10

\begin{tabular}{|l|c|c|c|c|c|c|c|c|}
\hline \multirow{3}{*}{ Stream } & Run & $\mathbf{U}$ & $\mathbf{P u}$ & $\mathbf{A m}$ & $\mathbf{C m}$ & $\mathbf{T c}$ & $\mathbf{C s}$ & $\mathbf{S r}$ \\
\cline { 2 - 10 } & Time & $\mathrm{g} / \mathrm{L}$ & $\mathrm{d} / \mathrm{m} / \mathrm{mL}$ & $\mathrm{d} / \mathrm{m} / \mathrm{mL}$ & $\mathrm{d} / \mathrm{m} / \mathrm{mL}$ & $\mathrm{d} / \mathrm{m} / \mathrm{mL}$ & $\mathrm{d} / \mathrm{m} / \mathrm{mL}$ & $\mathrm{d} / \mathrm{m} / \mathrm{mL}$ \\
\hline \multirow{3}{*}{ Product } & 3 & 78.0 & $7.58 \mathrm{E}+03$ & $1.05 \mathrm{E}+04$ & $2.70 \mathrm{E}+03$ & NA & $1.62 \mathrm{E}+04$ & $7.45 \mathrm{E}+03$ \\
\cline { 2 - 10 } & 5 & 72.3 & $2.30 \mathrm{E}+03$ & $1.68 \mathrm{E}+03$ & $4.31 \mathrm{E}+02$ & NA & $4.93 \mathrm{E}+03$ & $3.35 \mathrm{E}+03$ \\
\hline Tc Product & 3 & NA & $1.79 \mathrm{E}+03$ & NA & NA & $2.61 \mathrm{E}+06$ & $1.16 \mathrm{E}+05$ & $2.14 \mathrm{E}+04$ \\
\cline { 2 - 9 } & 5 & NA & $1.92 \mathrm{E}+04$ & $1.36 \mathrm{E}+04$ & $3.49 \mathrm{E}+03$ & $2.02 \mathrm{E}+06$ & $3.81 \mathrm{E}+05$ & $1.99 \mathrm{E}+05$ \\
\hline \multirow{2}{*}{$\begin{array}{c}\text { Waste } \\
\text { Raffinate }\end{array}$} & 3 & NA & NA & NA & NA & NA & NA & NA \\
\cline { 2 - 9 } & 5 & NA & $1.11 \mathrm{E}+09$ & NA & NA & NA & NA & $2.12 \mathrm{E}+10$ \\
\hline
\end{tabular}

NA - Not Available

Table XIV: Mass Balances for Test 3B with Feed in Stage 10

\begin{tabular}{|l|c|c|c|c|c|c|c|c|}
\hline \multirow{3}{*}{ Stream } & Run & $\mathbf{U}$ & $\mathbf{P u}$ & $\mathbf{A m}$ & $\mathbf{C m}$ & $\mathbf{T c}$ & $\mathbf{C s}$ & $\mathbf{S r}$ \\
\cline { 3 - 9 } & Time & $\%$ & $\%$ & $\%$ & $\%$ & $\%$ & $\%$ & $\%$ \\
\hline U Product & 3 & 111 & $3.80 \mathrm{E}-03$ & $4.03 \mathrm{E}-03$ & $1.21 \mathrm{E}-02$ & NA & $3.19 \mathrm{E}-04$ & $1.42 \mathrm{E}-04$ \\
\cline { 2 - 9 } & 5 & 102 & $6.04 \mathrm{E}-04$ & $6.42 \mathrm{E}-04$ & $1.92 \mathrm{E}-03$ & NA & $9.68 \mathrm{E}-05$ & $<6.7 \mathrm{E}-05$ \\
\hline Tc Product & 3 & NA & $2.96 \mathrm{E}-04$ & NA & NA & 81 & $1.05 \mathrm{E}-03$ & $1.86 \mathrm{E}-04$ \\
\cline { 2 - 9 } & 5 & NA & $3.03 \mathrm{E}-03$ & $2.27 \mathrm{E}-03$ & NA & 60 & $3.27 \mathrm{E}-03$ & $1.65 \mathrm{E}-03$ \\
\hline \multirow{2}{*}{$\begin{array}{c}\text { Waste } \\
\text { Raffinate }\end{array}$} & 3 & NA & NA & NA & NA & NA & NA & NA \\
\cline { 2 - 9 } & 5 & NA & 137 & NA & NA & NA & NA & 138 \\
\hline
\end{tabular}

NA - Not Available

Table XV: Analytical Data for Test 3B with Feed in Stage 8

\begin{tabular}{|l|c|c|c|c|c|c|c|c|}
\hline \multirow{3}{*}{ Stream } & $\begin{array}{c}\text { Run } \\
\text { Time }\end{array}$ & $\mathbf{U}$ & $\mathbf{P u}$ & $\mathbf{A m}$ & $\mathbf{C m}$ & $\mathbf{T c}$ & $\mathbf{C s}$ & $\mathbf{S r}$ \\
\hline \multirow{3}{*}{ U Product } & 3 & 63 & $2.08 \mathrm{~d} / \mathrm{m}+04 \mathrm{~mL}$ & $\mathrm{~d} / \mathrm{m} / \mathrm{mL}$ & $\mathrm{d} / \mathrm{m} / \mathrm{mL}$ & $\mathrm{d} / \mathrm{m} / \mathrm{mL}$ & $\mathrm{d} / \mathrm{m} / \mathrm{mL}$ & $\mathrm{d} / \mathrm{m} / \mathrm{mL}$ \\
\cline { 2 - 9 } & 6.5 & 70 & $1.59 \mathrm{E}+04$ & NA & NA & NA & $1.30 \mathrm{E}+03$ & $3.35 \mathrm{E}+03$ \\
\hline Tc Product & 3 & $2.4 \mathrm{E}-04$ & $8.4 \mathrm{E}+03$ & $9.8 \mathrm{E}+03$ & $2.5 \mathrm{E}+03$ & $1.9 \mathrm{E}+06$ & $5.5 \mathrm{E}+04$ & $3.9 \mathrm{E}+04$ \\
\cline { 2 - 9 } & 6.5 & $6.6 \mathrm{E}-04$ & $1.8 \mathrm{E}+04$ & $9.0 \mathrm{E}+03$ & $2.3 \mathrm{E}+03$ & $2.7 \mathrm{E}+06$ & $1.6 \mathrm{E}+05$ & $7.9 \mathrm{E}+04$ \\
\hline \multirow{2}{*}{$\begin{array}{c}\text { Waste } \\
\text { Raffinate }\end{array}$} & 3 & NA & NA & NA & NA & NA & NA & $1.79 \mathrm{E}+10$ \\
\cline { 2 - 9 } & 6.5 & NA & $8.24 \mathrm{E}+08$ & NA & NA & NA & NA & $1.23 \mathrm{E}+10$ \\
\hline
\end{tabular}

NA - Not Available 
The samples from test 3B (feed in stage 10) may not be at steady state due to the hydraulic upsets. Note that the $\mathrm{U}$ concentration in the product increased from test $3 \mathrm{~A}$ due to lower total flow of that stream. The U mass balance is good for the last sample, but high for the first sample taken immediately prior to the hydraulic upset. The Tc concentration in the Tc product also increased in proportion to the decrease in strip flow rate. However, the mass balance is very low and appears to be decreasing. It is uncertain whether the results are due to the hydraulic upset. The data for $\mathrm{Pu}$ and Am appear to be high in the first sample, especially for Am. The results could reflect decreasing the number of scrub stages by two relative to test $3 \mathrm{~A}$; however, the second sample shows much lower $\mathrm{Pu}$ and $\mathrm{Am}$ values. The difference again could be related to the hydraulic upset that was observed immediately after the first sample. The total TRU isotopes in the $\mathrm{U}$ product stream for the second sample is $29 \mathrm{nCi}$ per gram which makes the $\mathrm{U}$ lower than Class C low level waste.

Table XVI: Mass Balances for Test 3B with Feed in Stage 8

\begin{tabular}{|c|c|c|c|c|c|c|c|c|}
\hline \multirow[b]{2}{*}{ Stream } & \multirow{2}{*}{$\begin{array}{l}\text { Run } \\
\text { Time }\end{array}$} & $\overline{\mathbf{U}}$ & $\overline{\mathbf{P u}}$ & $\overline{A m}$ & $\mathbf{C m}$ & Tc & Cs & $\mathbf{S r}$ \\
\hline & & $\%$ & $\%$ & $\%$ & $\%$ & $\%$ & $\%$ & $\%$ \\
\hline \multirow[t]{2}{*}{ U Product } & 3 & 94.4 & $1.00 \mathrm{E}-04$ & $1.07 \mathrm{E}-04$ & $3.19 \mathrm{E}-04$ & NA & $\mathrm{NA}$ & $6.67 \mathrm{E}-05$ \\
\hline & 6.5 & 97.0 & $5.62 \mathrm{E}-03$ & NA & NA & NA & $2.51 \mathrm{E}-05$ & $6.24 \mathrm{E}-05$ \\
\hline \multirow[t]{2}{*}{ Tc Product } & 3 & NA & $1.42 \mathrm{E}-03$ & $1.77 \mathrm{E}-03$ & $5.29 \mathrm{E}-03$ & 59 & $5.08 \mathrm{E}-04$ & $3.46 \mathrm{E}-04$ \\
\hline & 6.5 & $4.1 \mathrm{E}-04$ & $2.83 \mathrm{E}-03$ & $1.52 \mathrm{E}-03$ & $4.54 \mathrm{E}-03$ & 82 & $1.35 \mathrm{E}-03$ & $6.55 \mathrm{E}-04$ \\
\hline \multirow{2}{*}{$\begin{array}{l}\text { Waste } \\
\text { Raffinate }\end{array}$} & 3 & $\mathrm{NA}$ & $\mathrm{NA}$ & NA & $\mathrm{NA}$ & NA & $\mathrm{NA}$ & 135.1 \\
\hline & 6.5 & NA & 118.3 & NA & NA & NA & NA & 93.3 \\
\hline
\end{tabular}

NA - Not Available

The $U$ mass balance for the portion of the test with the feed in stage 8 appears to be within expected uncertainty in flow rates and analyses. The percent of Tc in the Tc product stream is similar to the amount recovered during operation with the feed in stage 10 .

Analyses for $\mathrm{Pu}$ in the $\mathrm{U}$ product stream show a large increase for the last two samples, but the Am does not increase remaining at a value similar to that observed at 4-6 hours in test 3A. The reason for change in $\mathrm{Pu}$ concentration is that $\mathrm{Pu}$ decontamination is dependent on AHA while Am decontamination is not, thus the increase is related to the AHA concentration in the scrub. These samples were taken as much as 28 hours after the last scrub was added to the scrub feed tank by mixing AHA with acid. It is known that AHA hydrolyzes in acid solutions (see equation 1$)^{7}$

$$
\mathrm{CH}_{3} \mathrm{CONHOH}+\mathrm{H}_{2} \mathrm{O}+\mathrm{H}^{+} \rightarrow \mathrm{RCOOH}+\mathrm{NH}_{3} \mathrm{OH}^{+}
$$

Taylor and May give a kinetic rate constant of $0.00205 \mathrm{~L} / \mathrm{mol}-\mathrm{min}$ for AHA hydrolysis at $25^{\circ} \mathrm{C}$ according to kinetic equation 2 .

$-\mathrm{d}[\mathrm{AHA}] / \mathrm{dt}=\mathrm{k}[\mathrm{AHA}]\left[\mathrm{H}^{+}\right]$ 
Calculation of the AHA concentration over the time of the test is shown in Figure 9. The figure shows that by the end of the test the AHA concentration was about one-third the initial concentration. The initial concentration was chosen to ensure sufficient AHA to complex $\mathrm{Pu}$ and reduce $\mathrm{Np}$. The $\mathrm{Pu}$ and $\mathrm{Np}$ concentrations in the Dresden fuel are lower than expected for higher burnup fuels so the concentration of AHA probably didn't have to be as high as $0.47 \mathrm{M}$ initially. That meant that some decomposition would not affect the Pu decontamination factor (DF). However, once the AHA concentration went below a minimum concentration, the AHA was not sufficient to maintain the $\mathrm{Pu} \mathrm{DF}$. The conclusion for the full-scale process is that AHA and $\mathrm{HNO}_{3}$ should be fed to the contactors as separate streams rather than being mixed prior to being fed to the contactors.

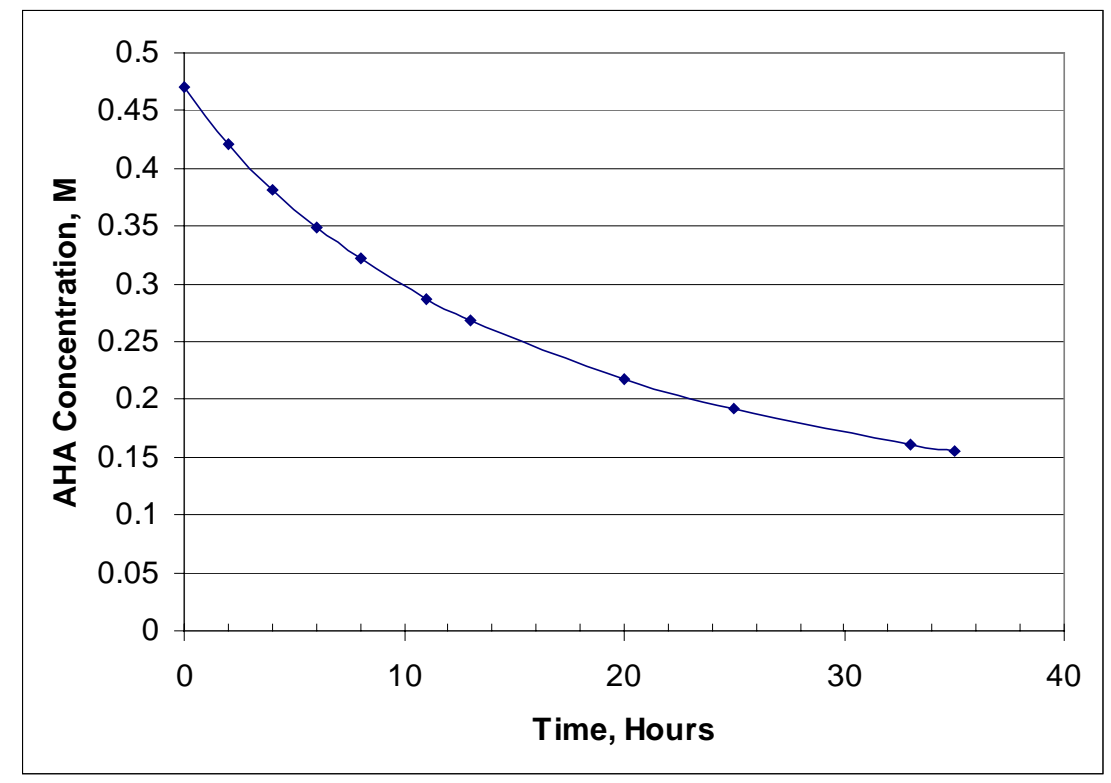

Figure 9: Calculated Decrease in AHA Concentration during Test 3

In summary, except for the TRU being high on the first test, the $U$ meets low level waste criteria in all three tests at baseline conditions. Testing at non-baseline conditions resulted in part of the $U$ product meeting low level waste criteria for TRU with the remainder above the limit of $100 \mathrm{nCi} / \mathrm{g}$. Table XVII shows a compilation of results from all the tests. 
WSRC-TR-2002-00444

Revision 0

Table XVII: Summary of Test Results and Low Level Waste Classes

\begin{tabular}{|l|c|c|r|c|c|c|c|}
\cline { 2 - 8 } \multicolumn{1}{c|}{} & \multicolumn{2}{c|}{ LLW Limit, Ci/cubic meter } & \multicolumn{4}{c|}{ UREX Test Results $^{\mathbf{a}}$} \\
\hline Nuclides & Class A & Class B & \multicolumn{1}{c|}{ Class C } & Test 1 & Test 2 & Test 3A & Test 3B \\
\hline Tc-99 & - & - & 3 & 0.34 & 0.03 & NA & NA \\
l-129 & - & - & 0.08 & NM & NM & NM & NM \\
Nuclides with half-life $<5 \mathrm{yr}$ & 700 & - & - & 0.05 & ND & ND & ND \\
Sr-90 & 0.04 & 150 & 7000 & 0.22 & 0.12 & $<0.07$ & $<0.07$ \\
Cs-137 & 1 & 44 & 4600 & 0.47 & 0.41 & 0.04 & $0.03-0.11$ \\
\hline TRU with half-life $>5$ yr & - & - & $100 \mathrm{nCi} / \mathrm{g}$ & 296 & 65 & 16 & $29-153$ \\
Pu-241 & - & - & $3500 \mathrm{nCi} / \mathrm{g}$ & 1420 & 214 & 71 & $147-1020$ \\
Cm-242 & - & - & $20000 \mathrm{nCi} / \mathrm{g}$ & ND & ND & ND & ND \\
\hline
\end{tabular}

${ }^{a}$ Assumes density of bulk $\cup_{3}$ is half the crystal density or $3.645 \mathrm{~g} / \mathrm{cc}$

NM - Not Measured; ND - Not Detected; NA Not Available

\section{Conclusions}

Demonstration of the UREX process at baseline conditions showed that the process will meet all goals for recovery and decontamination. The goals for the UREX process are to produce a $\mathrm{U}$ product that is Class $\mathrm{C}$ low level waste or lower, recover $>99.9 \%$ of the $\mathrm{U}$ and $>95 \%$ of the Tc, reject $>99.9 \%$ of the Pu to the raffinate, and the U concentration in the Tc product $<0.01 \%$ of the Tc. All three tests showed Cs being lower than the Class A limit of $1 \mathrm{Ci}$ per cubic meter. Strontium was low Class B for the first two tests and very close Class $\mathrm{A}$ in the third test (the Sr was below the detectability limit of the method in the third test). In fact, the third test resulted in a TRU isotope concentration of only 16 $\mathrm{nCi}$ per gram of $\mathrm{U}$. The $\mathrm{U}$ losses to the Tc and raffinate streams totaled $0.011 \%$ of the $\mathrm{U}$ fed to the process in the first test. U loss to the raffinate was $0.016 \%$ in the second test.

Tc losses to the U stream were $1.2 \%$ in the first test and $0.1 \%$ in the second test while losses to the raffinate were low in both tests. These results prove that $>95 \%$ of Tc can be recovered from the feed.

Loss of $\mathrm{Pu}$ and other actinides to the $\mathrm{Tc}$ and $\mathrm{U}$ product streams was $<0.1 \%$ in all first two tests of the baseline flowsheet with $>99.9 \%$ going to the raffinate.

\section{Future Work}

Analyses of the remaining samples including stage samples from tests 2 and 3B need to be completed to give more information on the tests. The analyses need to include acid concentrations in the stage samples from the extraction and scrub section. Better analyses of the feed are needed to help clarify the mass balances Pu and Tc in the different tests. Stage samples need to be compared with calculations from the AMUSE computer code to validate the code so that the flowsheet can be optimized to obtain the best performance without extensive laboratory tests. 
WSRC-TR-2002-00444

Revision 0

\section{References}

1. J. J. Laidler, L. Burris, E. D. Collins, J. Duguid, R. N. Henry, E. J. Karell, S. M. McDeavit, M. Thompson, M. A. Williamson, and J. L. Willit, Prog. Nucl. Ener., 38, 65-79 (2001).

2. R.J. Taylor, I. May, A.L. Wallwork, I.S. Denniss, N.J. Hill, B.Ya. Galkin, B.Ya. Zilberman, and Yu.S. Fedorov, J. Alloys and Comp., 271-273, 534-537 (1998).

3. May, R.J. Taylor, and G. Brown, J. Alloys and Comp., 271-273, 650-653 (1998).

4. L. Nunez and G. F. Vandegrift, Evaluation of Hydroxamic Acid in Uranium Extraction Process: Literature Review, ANL-00/35, Argonne National Laboratory March, 2001.

5. May, R.J. Taylor, I.S. Denniss, G. Brown, A.L. Wallwork, N.J. Hill , J. M. Rawson, and R. Less, J. Alloys and Comp., 275-277, 769-772 (1998).

6. B. J. Colston, G. R. Choppin, and R. J. Taylor, Radiochim. Acta, 88, 329-334 (2000).

7. R.J. Taylor and I. May, Czech. J. Phys., 49, 617-621 (1999).

8. Regalbuto, M. C., Copple, J. M. and Vandegrift, G. F., "Development of an Optimized UREX Flowsheet for the ATW Program Using USEM", Separation Science and Technology (in press).

9. G. F. Kessinger, M. C. Thompson, and D. D. Diprete, "Dissolution of Dresden Reactor Fuel," WSRC-TR-2002-00448, Revision 0, September 30, 2002.

10. S. G. Campbell, M. W. Geeting, C. W. Kennell, J. D. Law, R. A. Leonard, M. A. Norato, R. A. Pierce, T. A. Todd, D. D. Walker, and W. R. Wilmarth, "Demonstration of Caustic-Side Solvent Extraction with Savannah River Site High Level Waste," WSRC-TR-2001-00223, Revision 0, April 19, 2001.

11. R. Lascola, Analysis of Mixer-Settler Bank Samples for Uranium by Diode Array Spectroscopy, WSRC-TR-2002-00284, Revision 0, June 13, 2002.

12. Boullis, B. and P. Baron. "Modelling of uranium/plutonium splitting in PUREX processes". Extraction '87: The Recovery of High Value Materials Symposium, Dounreay UK, pp. 323-330, (1987). 